ROCZNIKI KULTUROZNAWCZE

Tom X, numer $1 \quad-\quad 2019$

DOI: http://dx.doi.org/10.18290/rkult.2019.10.1-3

TOMASZ GRĘBSKI

\title{
MODELOWANIE MATEMATYCZNE W MUZYCE NA PODSTAWIE TWÓRCZOŚCI IANNISA XENAKISA
}

\begin{abstract}
Każdą muzykę można w końcu rozłożyć na szereg operacji i układów o charakterze czysto logicznym. Dźwięki lub struktury dźwiękowe należy traktować jako znaki, jako dźwiękowe symbole stanowiące swoiste elementy oszernego zbioru, w którym i do którego stosować można teorię zbiorów, rozmaite systemy logiczne $\mathrm{i}$ algebraiczne ${ }^{1}$.
\end{abstract}

Iannis Xenakis

\section{WSTĘP}

Poszukiwanie relacji między matematyką a muzyką jest przedmiotem wielu zjawisk badawczych. Istnieją utwory, w których kompozytor świadomie wykorzystywał wiedzę matematyczną podczas komponowania, jednak zdecydowana większość utworów nie była w żaden sposób inspirowana matematyką.

Wiele opisanych przykładów zależności między matematyką a muzyką można znaleźć w literaturze. Na szczególną uwagę zasługują:

- książka Eduarda Hanslicka Vom Musikalisch-Schönen, w której autor broni tezy, że istotą muzyki jest jej forma (muzyka czysta) ${ }^{2}$,

- książka Carla Dahlhausa Estetyka w muzyce, w której według autora „wyobrażenie, iż celem muzyki ma być przedstawienie i wzbudzanie

Mgr TOMASZ GrĘBSKI - Zespół Szkół nr 2 im. Mikołaja Reja w Kraśniku, Doktorant na Wydziale Filozofii Katolickiego Uniwersytetu Lubelskiego Jana Pawła II, e-mail: tomasz@rey.edu.pl; ORCID: 0000-0003-2943-9327.

${ }^{1}$ Iannis XENAKIS, „Debussy a sformalizowanie muzyki”, Ruch muzyczny nr 16 (1962): 7.

${ }^{2}$ Eduard Hanslick, Von Musikalisch-Schönen (Leipzig: Breitkopf \& Härtel, 1854). 
afektów, stanowi topos zakorzeniony w historii nie mniej głęboko niż teza przeciwna, że muzyka jest dźwiękową matematyką"”,

- książka amerykańskiego fizyka i informatyka Douglasa R. Hofstadtera Gödel, Escher, Bach: An Eternal Golden Braid, w której autor zestawia myśl wielkiego matematyka i logika Kurta Gödela z artystycznymi wizjami holenderskiego malarza i grafika Mauritsa Cornelisa Eschera oraz muzyką Jana Sebastiana Bacha ${ }^{4}$,

- książka pianistki i filozof Anny Brożek Symetria w muzyce czyli o pierwiastku racjonalnym $w$ komponowaniu dziet muzycznych ${ }^{5}, \mathrm{w}$ której autorka pisze m.in. na temat symetrii w muzyce, a także potrzebie jej występowania,

- książka Music and Mathematics. From Pythagoras to Fractals pod red. J. Fauvela, R. Flooda, R. Wilsona, w której możemy przeczytać m.in. o matematycznych strukturach dźwięku, o geometrii muzyki, o wykorzystaniu kombinatoryki, a także o fraktalnych kompozycjach ${ }^{6}$,

- referat Edyty Orman Muzyka na tle innych sztuk w ujęciu Thrabsybulosa Georgiadesa o matematyczno-pitagorejskim paradygmacie rozumienia muzyki ${ }^{7}$,

- rozprawa G. Diaz-Jereza Algoritmic music: using mathematical models in music composition, w której autor pisze m.in. o użyciu matematycznych modeli oraz struktur stochastycznych i fraktalnych w muzyce algorytmicznej.

Oczywistym jest, że w zasadzie każdy rodzaj muzyki cechuje jakiś rodzaj „matematyczności”, co wynika już stąd, że jej materiał dźwiękowy ma strukturę dziedziczoną po części po skalach muzycznych zbudowanych z interwałów, takich np. jak tetrachord, a te można wyrażać i przedstawiać za pomocą prostych proporcji arytmetycznych, czego świadomi byli już starożytni filozofowie, m.in. Archytas z Tarentu (pierwsza połowa IV w. p.n.e.) czy Arystoksenos (IV w. p.n.e., uczeń Arystotelesa). Arystoksenos stosował ogólne zasady empiryzmu w swoich analizach dotyczących budowy instrumentów czy konstrukcji skal muzycznych oraz, jako empiryk, odwoływał się

\footnotetext{
${ }^{3}$ Carl DahlHaus, Estetyka muzyki (Warszawa: Wydawnictwo UW, 2015), 20.

${ }^{4}$ Douglas Richard Hofstadter, Gödel, Escher, Bach: An Eternal Golden Braid (New York: Basic Books, 1979).

${ }^{5}$ Anna BrożEK, Symetria w muzyce (Tarnów: Biblos, 2004).

${ }^{6}$ John Fauvel, Raymond Flood, Robin Wilson, ed., Music and Mathematics. From Pythagoras to Fractals (Oxford: Oxford University Press, 2003).

${ }^{7}$ Edyta OrMan, „Muzyka na tle innych sztuk w ujęciu Thrabsybulosa Georgiadesa”, W 10 Polski Zjazd Filozoficzny 15-19 września 2015 Poznań, red. Lidia Godek, Maciej Musiał, Marek Woszczek (Poznań: Wydawnictwo Naukowe Instytutu Filozofii UAM, 2015), 230.

${ }^{8}$ Gustavo DiAZ-JEREZ, Algorytmic music: using mathematical models in music composition, [maszynopis] (The Manhattan School: 2000), 54-65.
} 
przede wszystkim do zastanej praktyki wykonawczej i doświadczenia słuchowego. Zarazem był racjonalistą - po części pitagorejczykiem, ale dane empiryczne analizował w świetle zasad logiki nakazującej m.in. jasno precyzować znaczenie podstawowych pojęć, a wysuwane tezy odpowiednio uzasadniać, stosując metodę indukcji. $Z$ tego powodu można uznać, że jego badania muzyki były po raz pierwszy w dziejach naukowe. Takie traktowanie muzyki zawdzięczamy bowiem pitagorejczykom, a jest ono - jakby twierdzić można - „spekulatywne” i nienaukowe. Jak jednak z metodologii nauk empirycznych wiadomo, spór o to, w jakiej mierze jakieś przed sięwzięcie filozoficzne jest naukowe w dzisiejszym tego słowa znaczeniu, a w jakim nie, nie ma jednoznacznych rozwiązań. $Z$ punktu widzenia skrajnego racjonalizmu to pitagoreizm był pierwszą próbą naukowego namysłu nad muzyką, lecz z punktu widzenia umiarkowanego empiryzmu - dopiero arystotelizm.

Próba powiązania matematyki $\mathrm{z}$ muzyką była podejmowana niejednokrotnie w wiekach późniejszych. Gottfried Wilhelm Leibniz (1646-1716) matematyk niemiecki - podkreślał, że w strukturze dźwiękowej muzyki obecne są elementy logiczne czy quasi-matematyczne. Stwierdził, że „muzyka fascynuje nas, chociaż jej piękno polega tylko na proporcji liczb oraz na liczeniu, którego nie jesteśmy świadomi, a które dusza przeprowadza"9. Kompozytor epoki baroku Jean-Philippe Rameau (1683-1764) powiedział: „Muzyka jest nauką, zatem powinna posiadać ściśle określone reguły wyprowadzone z jakiejś ewidentnej zasady, a zasada ta może być rozpoznana tylko za pomocą matematyki”.

W dalszej części artykułu będą używane dwa pojęcia (autorskie neologizmy): pierwsze z nich to „matematyzowanie muzyki” - przez to pojęcie należy rozumieć poszukiwanie i odkrywanie struktur czy obiektów matematycznych $^{10} \mathrm{w}$ muzyce, oraz drugie - „umuzycznianie matematyki”, przez które należy rozumieć świadome wykorzystanie struktur czy obiektów matematycznych w muzyce.

Zatem jeśli przyjmiemy powyższą definicję, to $\mathrm{z}$,matematyzowaniem muzyki” mamy do czynienia od dawna. Ale czy proces „umuzyczniania matematyki” jest możliwy? Czy obiekty matematyczne można „przetworzyć” w jakieś słyszalne dźwięki? Czy w jakiś sposób można je przedstawić w kompozycji muzycznej? Celem artykułu jest próba odpowiedzi na te pytania oraz

\footnotetext{
${ }^{9}$ Władysław Tatarkiewicz, Dzieje sześciu pojęć (Warszawa: PWN, 1988), 124.

${ }^{10}$ Obiekt matematyczny należy rozumieć jako obiekt abstrakcyjny, będący przedmiotem rozważań matematyki. Obiektami matematycznymi są m.in. liczby, permutacje, macierze, funkcje, relacje, przestrzenie, topologie, figury geometryczne, grupy, pierścienie itp.
} 
analiza zdefiniowanego pojęcia „umuzyczniania matematyki” i modelowania matematycznego w muzyce na przykładzie wybranych struktur matematycznych w kompozycjach Iannisa Xenakisa.

Aby było to możliwe należy wyeksponować sam proces twórczy, często zrezygnować z tradycyjnych sposobów komponowania i skupić się wyłącznie na matematycznym porządku. Ale czy taki utwór będzie piękny w klasycznym znaczeniu słowa „piękny”? Porządek matematyczny nie jest tożsamy z wartościowaniem estetycznym. J. Barrow w swej książce Wszechświat a sztuka pisze: „W matematyce reguły rządzące dopuszczalnymi przekształceniami logicznymi są jednoznacznie przedstawione w łatwo zrozumiały sposób. Jeśli narysujemy mapę, przedstawiającą ogromny obszar dedukcji matematycznych, wywodzących się z założeń początkowych, czyli aksjomatów, okaże się, że część z nich jest nieinteresująca dla matematyków. Wszystkie jednak będą wchodziły w skład tak zdefiniowanej matematyki. W muzyce jest jednak inaczej: jeżeli zbudujemy podobną mapę, to większość tak stworzonego „obszaru” muzyki będzie zdecydowaną kakofonią dźwięków, absolutnie niekwalifikującą się jako muzyka w konwencjonalnym sensie. Dlatego zdefiniowanie muzyki jako ciągu dźwięków generowanych za pomocą określonych reguł nie odróżnia muzyki od hałasu" ${ }^{11}$. Czy Barrow ma rację? Czy piękne to to samo, co ładne i przyjemne? Czy np. obrazy oparte na deformacji są ładne? Gdzie jest granica między wrażliwością a matematycznością i porządkiem? Może muzyka rzeczywiście powinna tylko umilać nam czas?

\section{MATEMATYCZNY PORZĄDEK W UTWORACH MUZYCZNYCH A WALORY ESTETYCZNE I ARTYSTYCZNE}

Gdy podziwiamy budowle architektoniczne, geometryczne kształty kryształów lub inne dzieła sztuki czy zachwycamy się wieloma kompozycjami muzycznymi, mamy wrażenie, że panuje $\mathrm{w}$ nich pewien przemyślany porządek, ład, odpowiednie proporcje i symetria. O samej symetrii $\mathrm{H}$. Weyl napisał: „symetria to idea, za pomocą której człowiek starał się przez wszystkie czasy ogarniać myślą i tworzyć: porządek, piękno i doskonałość" . Symetria „wedle Wielkiej Teorii, jest uzasadnieniem jej piękna. Obecność piękna zaznacza się bowiem poprzez wprowadzenie miar, uporządkowania

\footnotetext{
${ }^{11}$ John BARrow, Wszechświat a sztuka, przeł. Janusz Skolimowski (Warszawa: Amber, 1998), 291.
} 
i stosowania zabiegów matematycznych". Stosowanie porządku w sztuce, w szczególności w muzyce ułatwia i uprzyjemnia jej odbiór. Słuchając muzyki, z jednej strony lubimy być zaskakiwani, ale z drugiej - lubimy pewną przewidywalność. Zastosowanie odpowiedniego porządku w utworze pozwala na to, aby zbytnia przewidywalność nie stała się nudna, a ciągłe zaskakiwanie zbyt męczące. Możemy więc przypuszczać, że matematyczne uporządkowania mogą wpływać na wartość estetyczną utworu muzycznego. Mówiąc o walorach estetycznych kompozycji muzycznej czy ogólnie dzieła sztuki, wkraczamy w estetykę - dziedzinę filozofii zajmującą się pięknem i innymi wartościami estetycznymi. M. Gołaszewska w swojej książce Zarys estetyki opisuje ją jako naukę zajmującą się tzw. sytuacją estetyczną, w skład której wchodzą: artysta (twórca), proces twórczy, dzieło sztuki, odbiorca, proces percepcji sztuki oraz wartości estetyczne. Postrzeganie tego, co jest piękne, ewaluowało od czasów starożytnych. Pojęcie piękna u starożytnych Greków pokrywało się z tym, co cenne i dobre. Według pitagorejczyków piękno istnieje obiektywnie i polega na mierze, proporcji, ładzie, jest ujmowane matematycznie. Według sofistów piękno nie istnieje obiektywnie, polega na (odbieranej przez kogoś) przyjemności dla oczu i uszu. Według Sokratesa piękno rzeczy polega na przydatności do stawianych im zadań, na stosowności. Platon uważał, że piękno to stosowność, przyjemność dla oczu i uszu, przy czym był skłonny pojmować je po pitagorejsku, jako proporcjonalny układ elementów wyrażony liczbą. Nowy pogląd na piękno przedstawił Plotyn, który zwrócił uwagę na to, że piękne bywają nie tylko rzeczy złożone, ale i proste. $\mathrm{Z}$ kolei Tomasz z Akwinu połączył ujęcie pitagorejsko-platońskie z plotyńskim.

Systemem estetyki jest jej historia, w której przenikają się myśli i doświadczenia o różnorodnej proweniencji ${ }^{12}$. Estetyka nie jest dyscypliną o wyraźnie określonym przedmiocie, lecz historią różnych problemów zogniskowanych wokół czterech myśli:

1. „Istnieje jedna estetyka dla wszystkich sztuk, a tylko ich materiał jest odmienny" 13 .

2. „Przyjemność estetyczna jest $\mathrm{z}$ istoty jedna i ta sama, niezależnie od tego, czy wywołuje ją dzieło sztuki, czy też bezpośredni ogląd natury i życia"14.

\footnotetext{
${ }^{12}$ Dahlhaus, Estetyka muzyki, 3.

${ }^{13}$ Robert SchumanN, Schriften über Music und Musiker, t. I (Leipzig: Georg Wigand's Verlag, 1888), 40.

${ }^{14}$ Arthur SCHOPENHAUer, Świat jako wola i przedstawienie, t. I, przeł. Jan Garewicz (Warszawa: PWN, 1994), 308.
} 
3. „Piękno nie jest punktem wyjścia, lecz uprawomocnieniem emancypacji poznania zmysłowego jako całości" ${ }^{15}$.

4. „Wszyscy ludzie, choćby nie znali sztuki i jej zasad, umieją sądzić ukrytym jakimś zmysłem, co jest dobrego, co złego w dziełach sztuki i jej zasadach"16.

$\mathrm{Na}$ powstanie dzieła muzycznego składa się wiele czynności, które są wyrazem różnych kategorii procesu formującego. Decydują one o jego rodzaju, gatunku, strukturze czy konstrukcji. Jedną z najważniejszych kategorii formowania dzieła jest jego struktura. Tworzy ona układ, w którym poszczególne współczynniki dzieła pozostają do siebie w ściśle określonym stosunku i decydują o jego integralności. Ten proces formujący zależy od jakości jego współczynników ${ }^{17}$.

Utwór muzyczny w zależności od użytych w nim środków kompozytorskich jest bliższym lub dalszym przedstawicielem określonej formy muzycznej. Forma to pojęcie trudne i wieloznaczne. Potocznie oznacza budowę, kształt. Każde dzieło sztuki, a więc także i dzieło muzyczne, ma określoną budowę - formę, która organizuje mniejsze i większe części utworu i ustala zasady ich relacji i powtórzeń. Pojęcie formy muzycznej rozważa się zazwyczaj w trzech aspektach: estetycznym, teoretycznym i praktycznym. Najbardziej skomplikowane struktury powstają wówczas, gdy do procesu formującego wchodzą czynności z różnych dziedzin sztuki czy nauki. Uzmysławianie estetycznych jakości muzycznych jest złożonym procesem zależnym nie tylko od struktury dzieła i zobiektywizowanych w nim relacji, ale także od aktów psychicznych rozgrywających się w samym umyśle bądź na jego styku ze światem zewnętrznym.

Relacja między matematyką a estetyką ma charakter szczególny, ponieważ harmonia, proporcjonalność czy symetria stały się w pewnym stopniu wyznacznikami piękna.

\footnotetext{
${ }^{15}$ Aleksander Baumgarten, Aesthetica (Frankfurt a. Oder: Traiecti as Viadrum Jo. Christ. Kleyb, 1750).

${ }^{16}$ CYCERON, „De oratore III 50”, w Historia estetyki, t. I, przeł. Władysław Tatarkiewicz (Warszawa: Arkady, 1985), 203.

17 Józef CHOMiŃSKI, Krystyna WiLkOwSKA-CHOMIŃSKA, Teoria formy (Kraków: Polskie Wydawnictwo Muzyczne, 1983), 20.
} 


\section{IANNIS XENAKIS - ARCHITEKT, INŻYNIER, KOMPOZYTOR}

Struktury czy modele matematyczne możemy zaobserwować w kompozycjach Iannisa Xenakisa. Jego twórczość jest doskonałym przykładem połączenia matematyki z muzyką, a połączenie tych dziedzin stało się u niego przedmiotem artystycznych dociekań. Aby lepiej zrozumieć jego twórczość i zasady, które stosował przy komponowaniu, warto poznać ważniejsze wydarzenia w jego życiorysie.

Iannis Xenakis urodził się 29 maja 1922 r. w Braila w Rumunii. Był najstarszym synem Klearchosa Xenakisa, greckiego biznesmena pochodzącego z greckiej wyspy Eubea i jego żony Fotini Pavlou pochodzącej również z greckiej wyspy - Lemnos. Jego matka zmarła na odrę, gdy Xenakis miał pięć lat, ale zdążyła zaszczepić w nim miłość do muzyki. Sam Xenakis wspomina, że mieszkając w Rumunii, słuchał radia, m.in. odbierał sygnały z Polski $-\mathrm{z}$ Katowic. Największe wrażenie zrobiła na nim V Symfonia Beethovena. W 1932 r. ojciec wysłał go wraz z braćmi do szkoły Spetsai, gdzie pobierał pierwsze nauki muzyki. Po ukończeniu szkoły w roku 1938 przeniósł się do Aten, aby przygotować się do egzaminów wstępnych na Narodowy Uniwersytet Techniczny w Atenach. Podczas studiów inżynierskich i architektonicznych kontynuował również lekcje muzyki w zakresie harmonii i kontrapunktu u Aristotelisa Koundouroffa - greckiego kompozytora tzw. ery modern. Pociągała go również filozofia, w szczególności platońska. Wtedy też zainteresował się relacjami między muzyką a matematyką, próbując znaleźć sposób na zastosowanie modeli matematycznych w muzyce.

W 1940 r. jego naukę przerwała druga wojna światowa. Xenakis brał udział w greckim ruchu oporu, a następnie w greckiej wojnie domowej. Został ciężko ranny, w wyniku czego stracił lewe oko. Pomimo wojny udało mu się w 1947 r. ukończyć politechnikę. Następnie został wcielony do narodowych sił zbrojnych. Wtedy też rząd grecki rozpoczął aresztowania byłych członków ruchu oporu. Xenakis, obawiając się aresztowania, zdezerterował i uciekł z kraju. Za to został skazany zaocznie na śmierć. Z Grecji uciekał poprzez Włochy, skąd trafił do Francji do Paryża. Przez wiele lat nie chciał mówić o tej ucieczce. W późniejszym okresie życia wyznał, że czuł ogromną winę za opuszczenie kraju i poczucie tej winy było jednym z powodów oddania się muzyce.

W 1959 r. w Paryżu został zatrudniony przez słynnego architekta Le Corbusiera. Jednocześnie poszukiwał nauczycieli muzyki, aby kontynuować naukę. Trafił do sław: szwajcarskiego kompozytora muzyki poważnej i filmowej Arthura Honeggera, potem do Dariusa Milhauda oraz do Oliviera 
Messiaena, który poradził mu, aby porzucił tradycyjne zajęcia muzyki, które nie są mu już potrzebne, a zajął się komponowaniem i wykorzystaniem w tym swej wiedzy matematycznej ${ }^{18}$. Słowa Messiaena potwierdziły wewnętrzne przekonanie Xenakisa. Znaczące w jego karierze muzycznej było również spotkanie $\mathrm{z}$ niemieckim dyrygentem Hermannem Scherchenem, który współpracował m.in. z twórcą muzyki dodekafonicznej Arnoldem Schönbergiem. Scherchen był otwarty na nowe koncepcje i twórczość Xenakisa go zainteresowała, w szczególności utwór Metastaseis. Wspierał Xenakisa w dalszej jego twórczości, a także zaproponował mu pisanie artykułów do swojego magazynu muzycznego Gravesaner-Blatter.

W 1950 r. Xenakis zainteresował się muzyką spoza Europy, m.in. z Indii, Laosu, Wietnamu, Chin i Japonii. Przez wiele lat poszukiwał nowych rozwiązań w muzyce i stwierdził, że instrumenty tradycyjne, jak np. fortepian, bardzo go ograniczają w zakresie komponowania. Dopiero rozwój nowoczesnych technik, informatyki, komputerów i przede wszystkim wykorzystanie wiedzy matematycznej, którą posiadał, pozwoliło mu realizować swoje muzyczne projekty. Sam Xenakis wspominał, że przez wiele lat zauważał ścisły związek między matematyką a muzyką, m.in. porównał kartezjański układ współrzędnych do systemu solfeżowego, który też jest dwuwymiarowy: czas oraz wysokość dźwięku ${ }^{19}$.

\section{PROCES KOMPONOWANIA}

Każdy rodzaj komponowania polega na wyborze poszczególnych elementów muzycznych z zasadniczo nieograniczonej różnorodności surowca dźwiękowego. Ponieważ zaś czynność ta ma na celu, jak w każdym rodzaju sztuki, wydobycie ładu czy stworzenie „dyscypliny” z „chaosu”, jednym z możliwych sposobów jej przeprowadzania jest metoda, która może odwoływać się do modelowania algebraicznego, do pewnych algorytmów opartych na teorii informacji czy rachunku prawdopodobieństwa albo np. teorii grup, a także do komputerowego programowania wspomagającego proces twórczy. Poszukiwanie takich metod może być jednym z elementów komponowania.

W jaki sposób Xenakis komponował swe dzieła i jak wykorzystywał przy tym wiedzę matematyczną? W 1970 r. skonstruował analogowo-cyfrowy

\footnotetext{
${ }^{18}$ Nouritza MAtossian, Xenakis (London: Kahn \& Averill, 1986).

${ }^{19}$ Gérard Montassier, Le fait culturel (Paris: Editions Fayard, 1980).
} 
konwerter, po raz pierwszy wyprodukowany w Europie przez Cemamu (Centre d'études mathématique et automatique musicales), której był założycielem wraz ze swymi przyjaciółmi. Kolejne urządzenie - UPIC łączyło rysunek elektroniczny i ołówek z komputerem i głośnikiem. Pozwalało ono komuś, kto nie znał się na muzyce, poprzez rysunek tworzyć różne kompozycje. Zastosowanie nowych technologii w muzyce nie przeszkadzało w jej rozwoju, a wręcz przeciwnie - pozwalało tworzyć nowe jej rodzaje, np. muzykę algorytmiczną. Twórcy takiej muzyki porównywani są dziś do astrofizyków, którzy badają tajemnice galaktyk. Jednak astrofizycy galaktyk nie tworzą, zaś muzycy rzeczywiście są twórcami swych ,muzycznych galaktyk”. Dla Xenakisa muzyka była rodzajem relacji między tym, co pisał jako muzyk, kierując się instynktem i zmysłami, a tym, co proponował komputer. Po jednym z koncertów w Musée Guimet w 1958 r. Xenakis przypuszczał, że zostanie proszony o komentarz do swego koncertu. Spisał więc wszystkie równania matematyczne, które wykorzystał podczas komponowania muzyki, ponieważ chciał pokazać, jak można wykorzystać matematykę w muzyce. Wielu słuchaczy stwierdziło, że skoro wykorzystywał matematyczne zależności, to jego muzyka musi być „zimna”. Xenakis uważał, że wiele osób odbiera muzykę na swój sposób i to bardzo różny, że nie zawsze odkryją od razu, co kompozytor miał na myśli i co wykorzystywał przy komponowaniu muzyki. Dotyczy to nie tylko muzyki współczesnej, ale także muzyki klasycznej (Bacha, Beethovena, Brahmsa, Chopina). Według niego muzyka nie od razu przekazuje intencje kompozytora, ale działa jako katalizator - zmysłowo i psychologicznie na wielu poziomach. Uważał, że rozwój muzyki jest uzależniony od rozwoju nowoczesnych technologii, jak również jest z nim ściśle związany. I tu nie miał żadnych wątpliwości, ponieważ dzięki nowej technologii zawsze będzie można stworzyć muzykę, której nigdy wcześniej nie słyszeliśmy. Gdy słyszymy muzykę Xenakisa, mamy do czynienia z czymś, co nie pasuje do żadnego układu odniesienia, który możemy znaleźć w muzyce. Nie usłyszymy w jego muzyce tego, co już wcześniej było. Sam Xenakis powiedział: „Wydaje się, że nowy typ muzyki jest konieczny. Artysta-konceptor nowego stylu musi posiadać wiedzę w tak różnych dziedzinach jak: matematyka, logika, fizyka, chemia, biologia, genetyka, paleontologia (dla ewolucji form), historia, mówiąc w skrócie, ma być uniwersalny, jednocześnie jednak musi kierować się w stronę form i architektury" ${ }^{20}$.

\footnotetext{
${ }^{20}$ Iannis XENAKIS, Art/Sciences: Alloys: the thesis defense of Iannis Xenakis before Olivier Messiaen, Michel Ragon, Olivier Revault dÁllonnes, Michel Serres and Bernard Tayssàdre (Styvesant, NY: Pendragon Press, 1985).
} 


\section{MASY DŹWIĘKOWE I PARABOLOIDA HIPERBOLICZNA}

Xenakis starał się zastosować w muzyce naturalne prawa rządzące różnymi zjawiskami, takimi jak szelest liści, uliczny zgiełk, odgłosy cyklad itd., tworząc musical dźwiękowych mas. Pierwszym utworem, który wyznaczał ten innowacyjny kierunek, jednocześnie pierwsze wielkie dzieło Xenakisa, był utwór Metastasis napisany w latach 1953-1954. Miało to miejsce bezpośrednio po studiach u Oliviera Messiaena. Kompozycja została napisana na orkiestrę dla 61 instrumentów i trwała 8 minut. Początkowo stanowiła ona część trylogii zatytułowanej Anastenaria (razem z Procession i Sacrifice). Potem Xenakis traktował ją już jako oddzielny utwór. Inspiracją do Metastasis było połączenie einsteinowskiego postrzegania czasu z utkwionymi w pamięci kompozytora odgłosami wojennymi (strzały, wybuchy) z matematycznymi strukturami Le Corbusiera. Muzyka zwykle składa się szeregu dźwięków uporządkowanych w czasie. Xenakis stosował rytm palindromiczny. Oznaczało to, że czas trwania nut jest taki sam, gdy odczytujemy go „od przodu” i „od tyłu”. Xenakis chciał pogodzić liniowe postrzeganie muzyki z relatywistycznym widzeniem czasu. Do wykonania tego utworu potrzeba 61 instrumentów: 12 dętych, 3 perkusistów grających na 7 instrumentach i 46 instrumentów smyczkowych. Przy czym każdy z dowolnie wybranych dwóch muzyków nie gra dwóch takich samych partii. To dokładnie tak, jak w funkcji różnowartościowej w matematyce. Utwór został napisany przy użyciu techniki masowego dźwięku, a każdy z wykonawców był odpowiedzialny za wykonanie glissand na różnych poziomach skoków i w różnym czasie. Newtonowskie spojrzenie na czas jest liniowe, zaś einsteinowskie jest funkcją materii $\mathrm{i}$ energii. Zmieniając jedną $\mathrm{z}$ tych wielkości, zmienia się czas. Xenakis próbował dokonać takiego podejścia w muzyce, tzn. podczas gdy większość tradycyjnych kompozycji zależy ściśle od czasu, niezmiennego metrum, tempa i długości frazy, Metastasis zmienia intensywność, rejestr i gęstość nut. To jest jak musical masy i energii. To przez te zmiany kompozycja w swej pierwszej i trzeciej części rozpędza się do przo$\mathrm{du}$, fragmenty nie mają nawet jakiejś melodii czy motywu, ale raczej zależy od siły tej konceptualizacji w czasie. Druga część ma pewną zauważalną melodię. Zastosowano tu zasadę dodekafonii, a czas trwania oparty jest na ciągu Fibonacciego i złotym podziale, który już wcześniej wielokrotnie był wykorzystywany w kompozycjach z różnych epok. Xenakis dość często wykorzystywał złoty podział również w swych projektach architektonicznych, np. Klasztor de la Tourette. Wstępny szkic czy zapis utworu Metastasis był 
zapisem graficznym, pokazującym masowe ruchy glissando. W rzeczywistości projekt ten stał się podstawą do projektu pawilonu Philips w Brukseli. Nie miał on płaskich powierzchni, lecz były to powierzchnie o kształcie paraboloidy hiperbolicznej. Jest to nieograniczona powierzchnia drugiego stopnia posiadająca jedną oś symetrii i dwie płaszczyzny symetrii, jest jedną z dwóch odmian paraboloidy obok paraboloidy eliptycznej. Powierzchnia ta powstaje w wyniku przesunięcia paraboli wzdłuż innej paraboli, przy czym obydwie parabole muszą spełniać następujące warunki:

- muszą się znajdować w płaszczyznach prostopadłych do siebie,

- ich osie symetrii muszą być równoległe,

- $\quad$ ich ramiona muszą być skierowane w przeciwne strony.

Paraboloida hiperboliczna ${ }^{21}$, niezależnie od jej ustawienia w przestrzeni i doboru układu współrzędnych, spełnia równanie powierzchni drugiego stopnia:

$\left(\frac{x}{a}\right)^{2}-\left(\frac{y}{b}\right)^{2}=z$

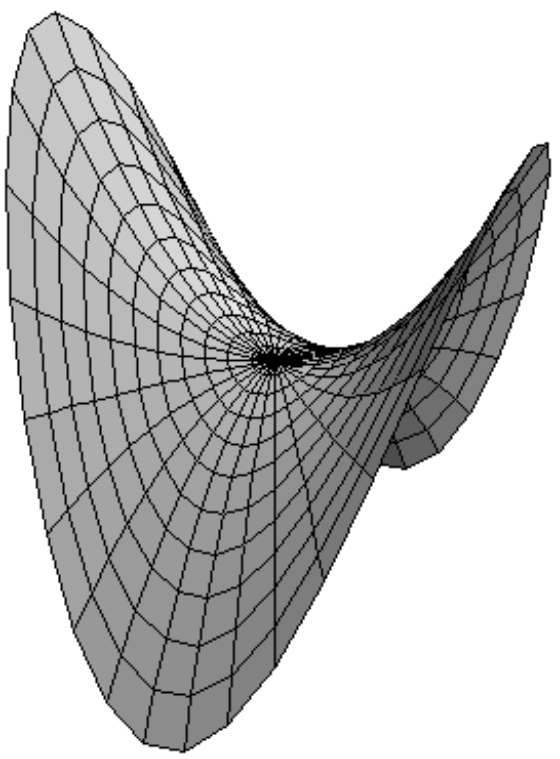

Rysunek1. Paraboloida hiperboliczna ${ }^{22}$

\footnotetext{
${ }^{21}$ Igor BRONSZTEJN, Konstantin SIEMIENDIAJEW, Matematyka - Poradnik encyklopedyczny (Warszawa: PWN, $\left.1976^{6}\right), 300$.

${ }^{22}$ https://commons.wikimedia.org/w/index.php?curid=68272, (dostęp: 4.03.2017).
} 
Podobne kształty widać na fragmencie zapisu kompozycji Metastasis.

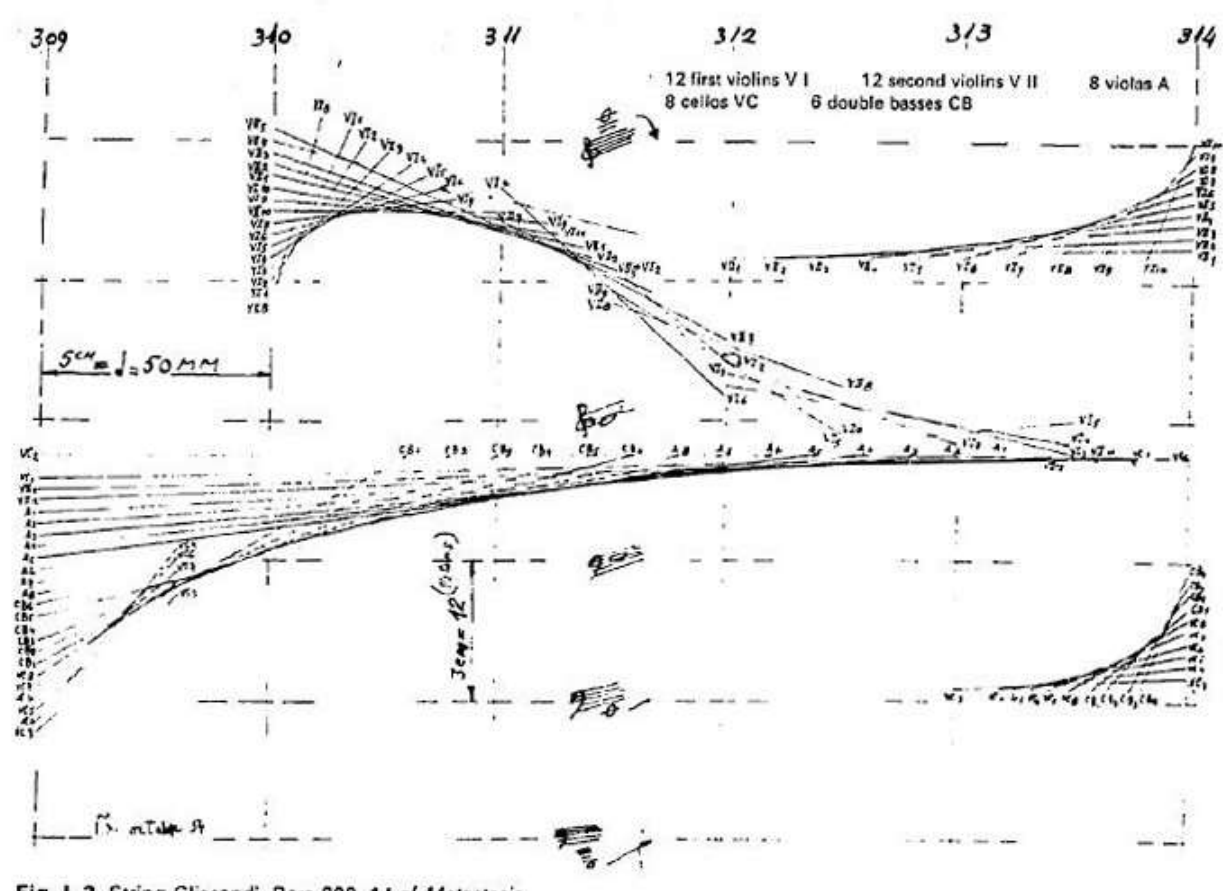

Fig. 1-2. String Glissandi. Bars 309-14 of Metastasis

Rysunek 2. Fragment zapisu kompozycji Metastasis I. Xenakisa ${ }^{23}$

Xenakis był wybitnym architektem, co z pewnością ułatwiało mu zastosowanie projektu matematyczno-muzycznego w architekturze. Projekt pawilonu Philipsa w Brukseli oraz sam pawilon składał się z dziewięciu powierzchni paraboloidy hiperbolicznej. Ta niezwykła budowla powstała na zlecenie firmy Philips na wystawę Expo ' 58 w Brukseli. W budynku przedstawiono wtedy multimedialne nowinki techniczne. Przykład ten pokazuje niezwykłe połączenie matematyki, muzyki i architektury.

\footnotetext{
${ }^{23}$ Iannis XenAKIs, Formalized Music (Hillsdale, N.Y.: Pendragon Press, 1992), 3.
} 

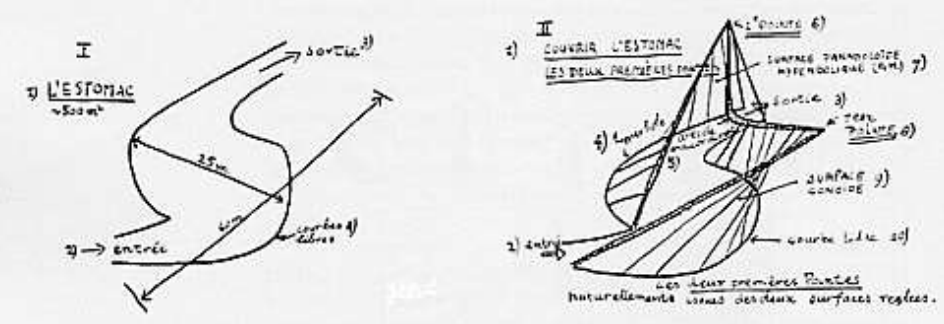

III UR TRDisient Dainte
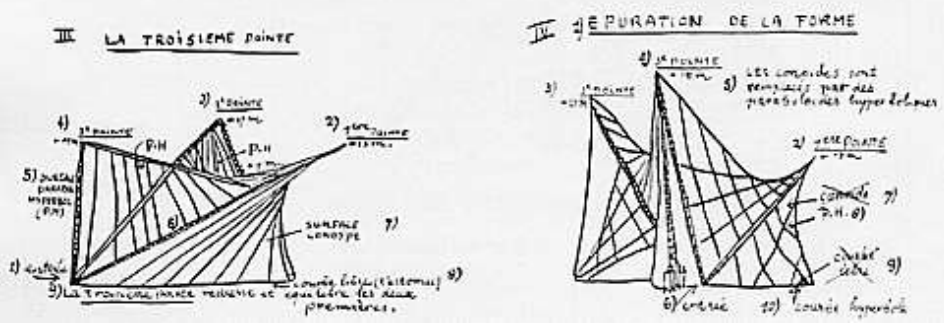

Rysunek 3. Szkice pawilonu Philipsa ${ }^{24}$

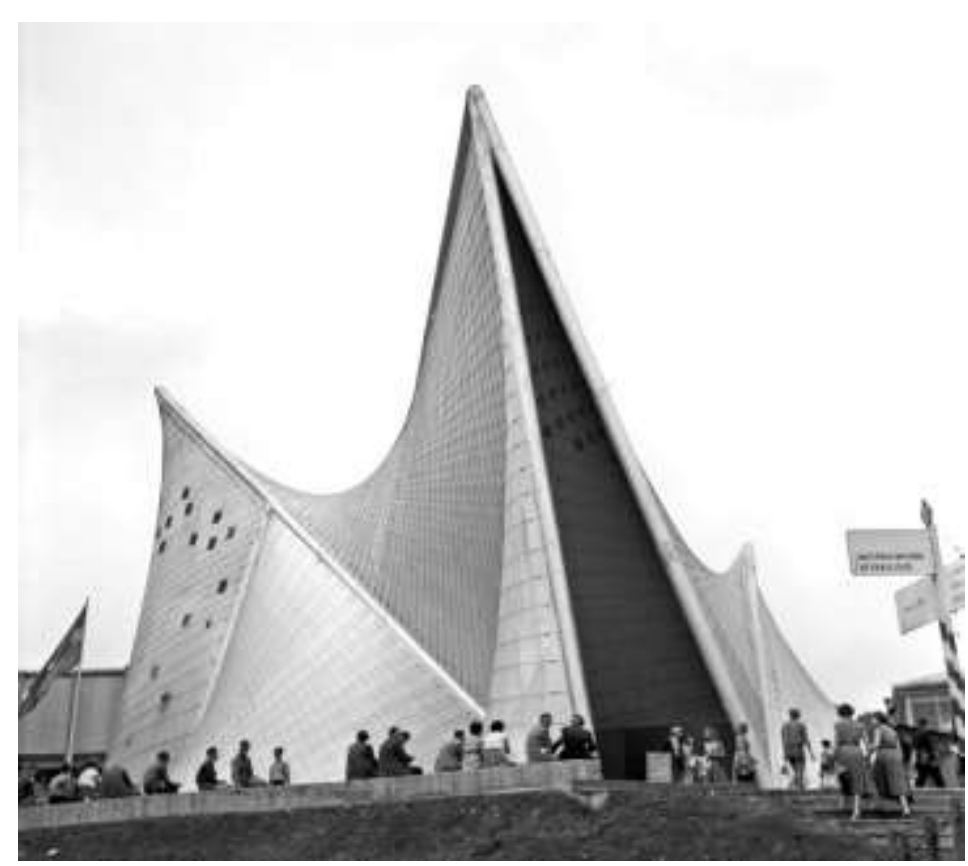

Rysunek 4. Pawilon Philipsa w Brukseli ${ }^{25}$

\footnotetext{
${ }^{24}$ https://en.wikiarquitectura.com/index.php/File:Pabellon_philips_boceto_2.jpg (dostęp: 4.04.2017).

${ }^{25} \mathrm{https}$ ///upload.wikimedia.org/wikipedia/commons/e/e7/Expo58_building_Philips.jpg (dostęp: 4.04.2017).
} 
Przy okazji budowli pawilonu Philipsa warto wspomnieć, że stała się ona inspiracją przy budowie stacji kolejowej Warszawa-Ochota. Dach tej konstrukcji ma kształt paraboloidy hiperbolicznej. Jest to projekt z okresu socmodernizmu zrealizowany w latach 1960-1962 autorstwa A. Romanowicza i P. Szymaniaka ${ }^{26}$.

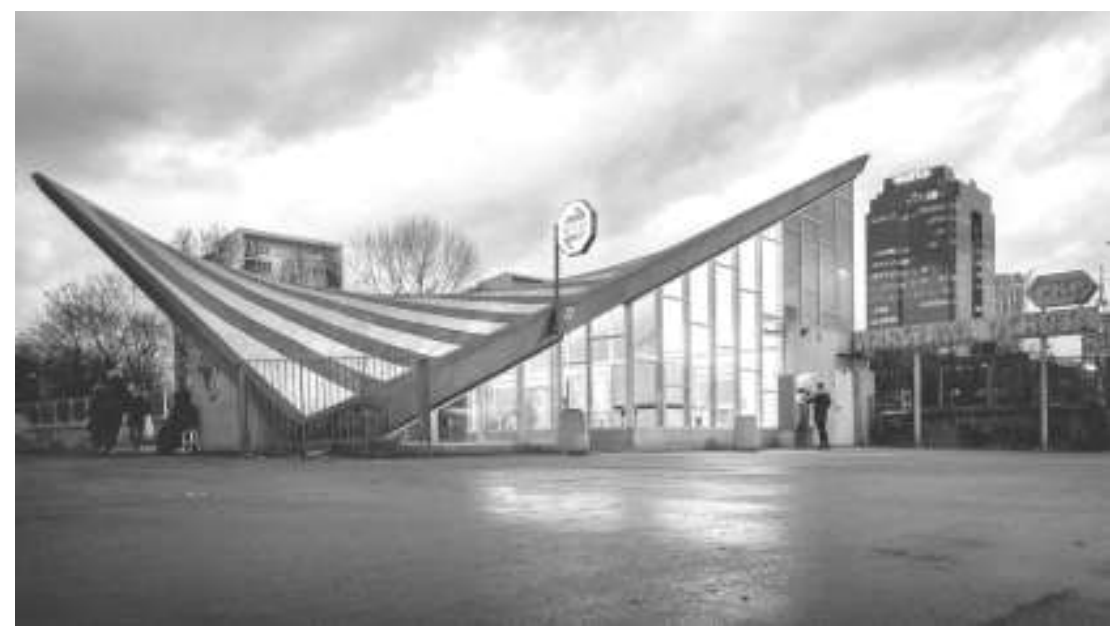

Rysunek 5. Budynek dworca Warszawa-Ochota widziany z Al. Jerozolimskich ${ }^{27}$

\section{PROCESY STOCHASTYCZNE I RACHUNEK PRAWDOPODOBIEŃSTWA}

Xenakis nigdy nie komponował przy fortepianie, nigdy nie zapisywał swych utworów za pomocą tradycyjnej notacji muzycznej. Jego narzędziem pracy była deska kreślarska i kalka techniczna ${ }^{28}$. Przy zapisie posługiwał się figurami i bryłami, do których przykładał wielką wagę, a w zapisie jego kompozycji można również dostrzec wykresy funkcji. Uważany jest on za twórcę muzyki stochastycznej, w której kompozycje powstają dzięki procesom stochastycznym. Sam Xenakis stwierdził, że brakowało do jego czasów kompozytora, który stosowałby przy komponowaniu naukowe struktury ${ }^{29}$.

\footnotetext{
${ }^{26} \mathrm{https}$ ://archirama.muratorplus.pl/architektura/modernizm-reaktywacja-odnowa-pawilonu-stacjipkp-ochota,67_19.html (dostęp: 4.04.2017).

${ }^{27}$ Radek KOŁAKOwsKI, Stacja Kolejowa Warszawa Ochota, zaprojektowana przez Aresniusza Romanowicza i Piotra Szymaniaka, zbudowana w 1962, https://commons.wikimedia.org/w/index. php?curid=47467617, (dostęp: 10.04 .2017$)$.

${ }^{28}$ Tomasz GręBSKI, „Muzyka sfer”, Wiedza i Życie nr 9 (969) (2015), 55-59.

${ }^{29}$ Iannis XENAKIS, „Stochastische Musik”, Gravesaner Blätter” 23/24 (1962): 156-168.
} 
W związku z coraz większą złożonością utworów jego muzyka wymagała odpowiedniego opisu naukowego, który przedstawił w swej książce Formalized Music. Thought and Mathematics in Music ${ }^{30}$. Dobrym przykładem ilustrującym ten fakt, jest utwór Achorripsis, w którym Xenakis stosował różne rozkłady prawdopodobieństwa ${ }^{31}$, m.in. rozkład wykładniczy, jednostajny, normalny, Poissona. Utwór swój przedstawił w formie tabeli, która jest podzielona na siedem sekcji instrumentów (wiersze) oraz 28 jednostek czasowych (kolumny). Poszczególne pola tabeli (jest ich 196) przedstawiają pięć różnych zdarzeń muzycznych, które różnią się przede wszystkim intensywnością dynamiki. Xenakis mówił o różnych gęstościach dźwiękowych, które to opisują liczbę zdarzeń dźwiękowych w takcie. Dwukrotne zdarzenie ma średnio dwa razy więcej zdarzeń muzycznych niż pojedyncze. W tabeli znajdują się również puste pola oraz odpowiednio zacieniowane i oznaczają ilość zdarzeń (od zera - puste pola, do czterech). Aby rozdzielić wspomniane typy zdarzeń najpierw ustalił, ile razy dane zdarzenie powinno się pojawić. Xenakis wykonał to przy użyciu rozkładu Poissona:

$$
P_{\lambda}(k)=\frac{\lambda^{k}}{k !} e^{-\lambda} \text {, gdzie } k \in\{0,1,2,3,4,5\}, \lambda \in R_{+}
$$

Przyjął, że $\lambda=0,6$ (zdarzeń/jednostkę) ${ }^{32}$.

Przy tych założeniach można obliczyć i utworzyć tabelę prawdopodobieństwa:

Przykładowe obliczenia dla $k=2$ i $\lambda=0,6$ :

$$
P_{2}=P_{0,6}(2)=\frac{(0,6)^{2}}{2 !} e^{-0,6} \approx 0,0988
$$

Zatem

$$
\begin{aligned}
& P_{0}=0,5488 \\
& P_{1}=0,3293 \\
& P_{2}=0,0988 \\
& P_{3}=0,0198
\end{aligned}
$$

\footnotetext{
${ }^{30}$ Iannis XENAKIs, Formalized Music. Thought and Mathematics in Music (Stuyvesant, NY: Pendragon Press, 1962).

${ }^{31}$ Rozkład prawdopodobieństwa - miara probabilistyczna określona na sigma-ciele podzbiorów zbioru wartości zmiennej losowej (wektora losowego), pozwalająca przypisywać prawdopodobieństwa zbiorom wartości tej zmiennej, odpowiadającym zdarzeniom losowym. Formalnie rozkład prawdopodobieństwa może być jednak rozpatrywany także bez stosowania zmiennych losowych.

${ }^{32}$ XenaKis, Formalized Music (1962), 29.
} 


$$
\begin{aligned}
& P_{4}=0,0030 \\
& P_{5}=0,0004,
\end{aligned}
$$

gdzie $P_{i}$ oznacza prawdopodobieństwo, że zdarzenie pojawi się $i$ razy w jednostce czasu, prędkości itp. Można teraz obliczyć prawdopodobieństwa wszystkich 196 pól tabeli (należy pomnożyć prawdopodobieństwa $P_{i}$ przez 196) $)^{33}$.

\begin{tabular}{|c|c|c|}
\hline Zdarzenie & Obliczenie rozkładu & Wartość użyta w tabeli \\
\hline Brak zdarzenia & $0,5488 \cdot 196=107,5640$ & 107 \\
\hline 1 zdarzenie & $0,3293 \cdot 196=64,5428$ & 65 \\
\hline 2 zdarzenia & $0,0988 \cdot 196=19,3648$ & 19 \\
\hline 3 zdarzenia & $0,0198 \cdot 196=3,8808$ & 4 \\
\hline 4 zdarzenia & $0,0030 \cdot 196=0,588$ & 1 \\
\hline 5 zdarzeń & $0,0004 \cdot 196=0,0784$ & 0 \\
\hline
\end{tabular}

Tabela1. Tabela liczby zdarzeń występowania w tabeli utworu Achorripsis

Z powyższych obliczeń wynika, ile ma nastąpić różnych zdarzeń. Ale jak Xenakis ułożył je w tabeli? W tym celu użył ponownie rozkładu Poissona. Wszystkich pól jest 196, więc 196/7 (instrumentów) daje 28 jednostek czasu. Autor przyjął, że $\lambda=2,32$ (liczba pojedynczych zdarzeń/liczba kolumn, czyli $65 / 28=2,32)^{34}$. Liczba zdarzeń w poszczególnych kolumnach przedstawia tabela 2 (obliczenia wykonano analogicznie jak w tabeli 1).

\begin{tabular}{|c|c|c|}
\hline Zdarzenie & Obliczenie rozkładu & Wartość zaokrąglona \\
\hline Liczba kolumn z 0 zdarzeniami & $0,09827 \cdot 28=2,7521$ & 3 \\
\hline Liczba kolumn z 1 zdarzeniem & $0,22799 \cdot 28=6,3839$ & 6 \\
\hline Liczba kolumn z 2 zdarzeniami & $0,26447 \cdot 28=7,4052$ & 8 \\
\hline Liczba kolumn z 3 zdarzeniami & $0,20453 \cdot 28=5,7268$ & 5 \\
\hline Liczba kolumn z 4 zdarzeniami & $0,11862 \cdot 28=3,3231$ & 3 \\
\hline Liczba kolumn z 5 zdarzeniami & $0,05504 \cdot 28=1,5411$ & 1 \\
\hline Liczba kolumn z 6 zdarzeniami & $0,02128 \cdot 28=0,5958$ & 1 \\
\hline Liczba kolumn z 7 zdarzeniami & $0,00705 \cdot 28=0,1974$ & 0 \\
\hline
\end{tabular}

Tabela 2. Tabela liczby zdarzeń występowania w kolumnach tabeli dla utworu Achorripsis

\footnotetext{
${ }^{33}$ XenAKIS, Formalized Music (1962), 29.

${ }^{34}$ Ibidem, s. 30.
} 
Jak teraz wyglądają rozkłady zdarzeń w poszczególnych wierszach? Tu również Xenakis stosował rozkłady prawdopodobieństwa. Długość całego utworu Achorripsis wynosi około 7 minut, co daje - przy równomiernym podziale na 28 kolumn - 15 sekund dla każdej kolumny ze stałym tempem $t=26$. Xenakis określił, że maksymalna liczba dźwięków powinna wynosić 10 na sekundę. Ta maksymalna liczba jest przeznaczona dla pola, w którym grane są cztery zdarzenia. Gęstość pojedynczych zdarzeń określona jest przez stosunek $10 / 4$, a potem podwójnych zdarzeń $10 / 4 * 2$, potrójnych $10 / 4 * 3$ i czterokrotnych $10 / 4 * 4$. W ten sposób powstają klasy rozpiętości zdarzeń, co przedstawia tabela 3 .

\begin{tabular}{|c|c|c|}
\hline Zdarzenie & Gęstość & Rozpiętość \\
\hline Brak zdarzenia & $0-0$ & 0 \\
\hline 1 zdarzenie & $6,5-2,5$ & 4 \\
\hline 2 zdarzenia & $11,5-8,5$ & 3 \\
\hline 3 zdarzenia & $17-14$ & 3 \\
\hline 4 zdarzenia & $20-20$ & 0 \\
\hline
\end{tabular}

Tabela 3. Tabela klas rozpiętości klas gęstości utworu Achorripsis

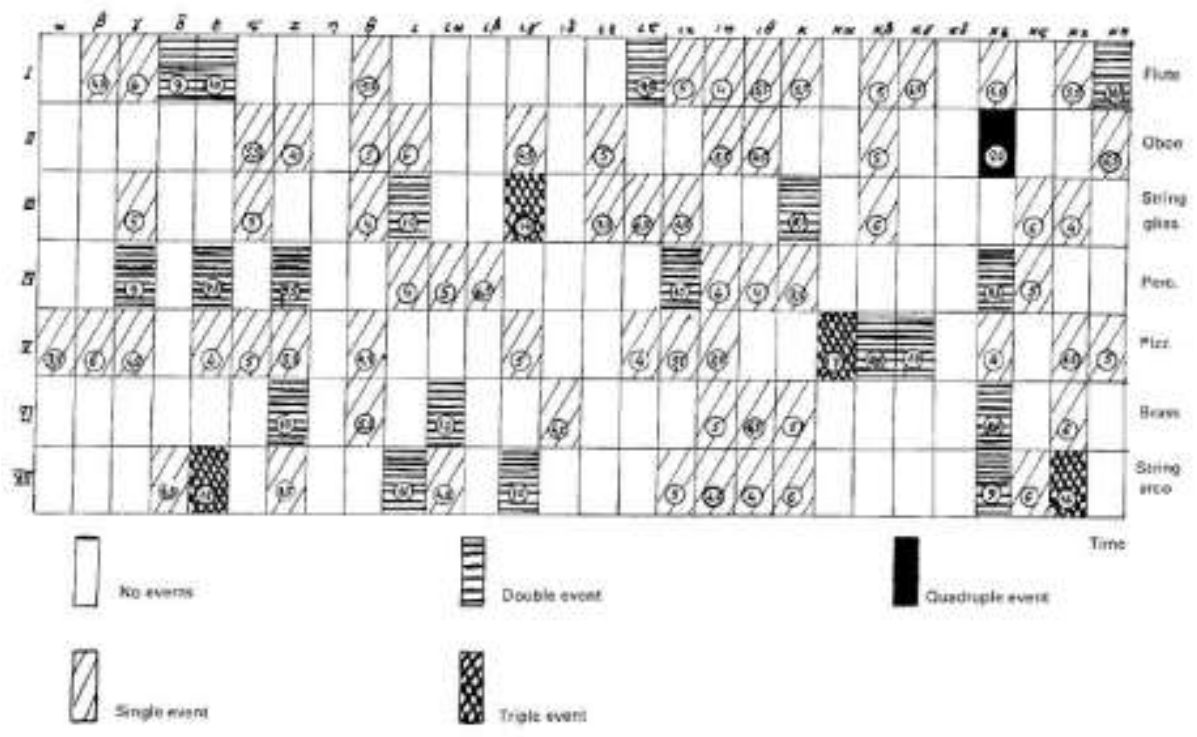

Fig. 1-9. Vector Matrix M, Matrix of Achomipsis

Rysunek 6. Tablica zdarzeń utworu Achorripsis ${ }^{35}$

\footnotetext{
${ }^{35}$ Xenakis, Formalized Music (1992), 28.
} 
Przykładowa analiza trzeciego wiersza tabeli na rysunku 6 utworu Achorripsis. Wiersz ten przedstawia glissando wykonywane przez instrumenty smyczkowe i jedną z jego cech, jaką jest prędkość. Rozkład wartości prędkości jest zgodny z rozkładem Gaussa:

$f(v)=\frac{2}{a \sqrt{\pi}} e^{\frac{-v^{2}}{a^{2}}}$

Prawdopodobieństwo, że wartość prędkości będzie między prędkością $v_{1}$ a prędkością $v_{2}$ :

$P(\lambda)=\theta\left(\lambda_{2}\right)-\theta\left(\lambda_{1}\right)$, gdzie $\theta(\lambda)=\frac{2}{\sqrt{\pi}} \int_{0}^{\lambda} e^{-\lambda^{2}} d \lambda$

Prawdopodobieństwo, że $i$-ty segment będzie miał długość $x$ wynosi: $P_{x}=\delta e^{-\delta x} d x$.

Zatem opisany przykład jest doskonałą ilustracją zastosowania rachunku prawdopodobieństwa na bardzo zaawansowanym poziomie, włączając $\mathrm{w}$ to różne rozkłady prawdopodobieństwa, od których zależało wiele zdarzeń muzycznych.

\section{TEORIA GRUP}

Xenakis wykorzystywał również w swych kompozycjach teorię mnogości i teorię grup. Grupa to pewien zbiór $G$, który ma następujące cechy:

- posiada jakieś elementy $(a, b, c, \ldots)$,

- w grupie określone jest pewne działanie (oznaczmy je przez *), a wynik tego działania należy do grupy,

- w grupie istnieje element neutralny $n$, taki, że $a^{*} n=a$,

- dla każdego elementu $a$ należącego do $G$ istnieje do niego element odwrotny: $a^{-1}$, taki że $a^{*} a^{-1}=n$,

- działanie określone w grupie jest łączne ${ }^{36}$.

Struktury algebraiczne, jakimi są grupy, można zauważyć w utworze Nomos Alpha. Jest to utwór (solo na wiolonczelę) napisany przez Xenakisa w 1965 r. na zlecenie radia Bremen dla wiolonczelisty Siegfrieda Palma, a dedykowany był trzem matematykom i filozofom. Pierwszy z nich to jeden z najwybitniejszych filozofów i teoretyków muzyki, uczeń Arystotelesa -

\footnotetext{
${ }^{36}$ Brożex, Symetria $w$ muzyce, 20.
} 
Arystoksenos (ok. 354 r. p.n.e. - 300 r. p.n.e.). Drugim był francuski matematyk Évariste Galois (1811-1832), który miał duże zasługi w rozwoju algebry. Trzecim zaś był niemiecki matematyk Felix Klein (1849-1925), który zajmował się geometrią, równaniami algebraicznymi, teorią funkcji i teorią grup, a także historią matematyki ${ }^{37}$.
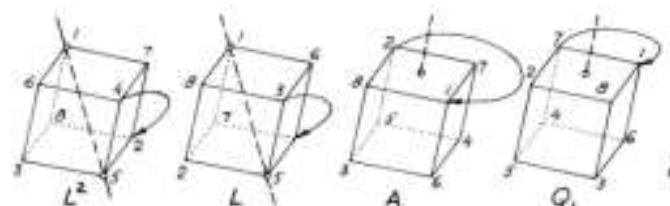

Q,
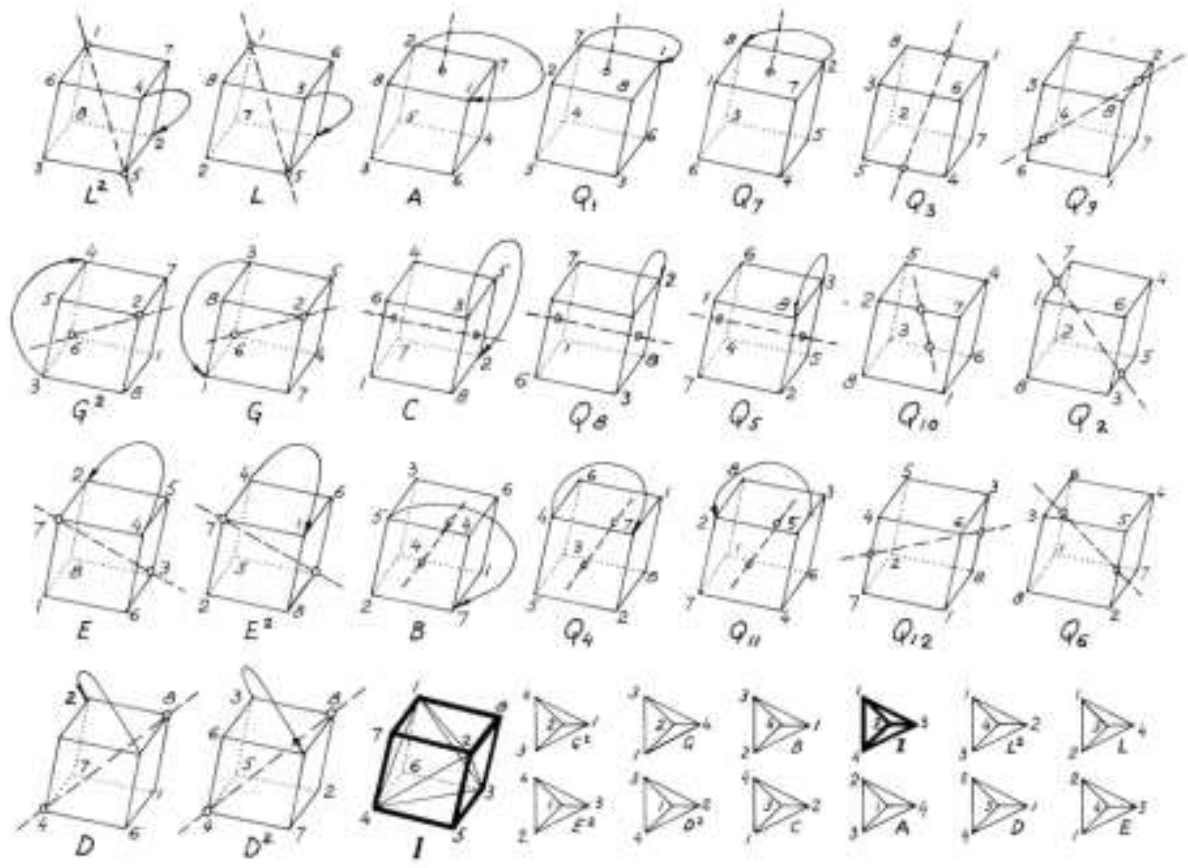

Rysunek 7. Iannis Xenakis: Nomos Alpha ${ }^{38}$

Kompozycja ta składa się z 24 sekcji podzielonych na dwie warstwy. Pierwsza warstwa zawiera sekcje niepodzielne przez cztery, zaś druga sekcja zawiera każdą podzielną przez cztery ${ }^{39}$. Warstwa pierwsza zależy od 24 elementowej grupy ośmiościennej izomorficznej ze skręceniem w sześcian. Elementami zestawu (zbioru) są permutacje, a operatorem binarnym jest kompozycja. Warstwa druga kontrastuje z warstwą pierwszą - nie jest określona przez teorię grup, ale zamiast tego jest w ciągłym ruchu registralnej

\footnotetext{
${ }^{37}$ Thomas DeLio, „Iannis Xenakis” „Nomos Alpha”: The Dialectics of Structure and Materials", Journal of Music Theory vol. 24, no. 1 (Spring, 1980): 63-95.

${ }^{38}$ XeNAKIS, Formalized Music (1992), 220.

${ }^{39}$ DeLio, „Iannis Xenakis' „Nomos Alpha”: The Dialectics of Structure and Materials”, 63.
} 
ewolucji ${ }^{40}$. Xenakis nazywał ten rodzaj kompozycji muzyką symboliczną, jest to taki styl muzyki, który korzysta $\mathrm{z}$ teorii mnogości, algebry abstrakcyjnej i logiki matematycznej w celu tworzenia i analizowania kompozycji muzycznych. Twórca krytycznie oceniał współczesną mu muzykę zachodnią, odkąd rozwój polifonii został zmniejszony, w porównaniu do muzyki ludowej czy tradycyjnej bizantyjskiej. Ta niekompletność muzyki zachodniej była główną inspiracją dla rozwoju muzyki symbolicznej, a najlepszym przykładem tego jest opisany utwór Nomos Alpha.

\section{RUCHY BROWNA I ŁAŃCUCHY MARKOWA}

Wyobraźmy sobie dowolną płaszczyznę, czyli dwuwymiarowy zbiór punktów. Załóżmy, że rozpoczynamy poruszanie się po tej płaszczyźnie w zupełnie losowy sposób: krok w prawo, potem w lewo, potem na „skos” itd. Zastanówmy się teraz, gdzie dojdziemy, poruszając się w ten sposób? Okazuje się, że po odpowiednim czasie (długim) przejdziemy przez każdy punkt płaszczyzny. Te pozornie chaotyczne ruchy to tzw. ruchy Browna. Robert Brown to słynny brytyjski botanik, biolog i chemik, który w $1827 \mathrm{r}$. odkrył nieregularne ruchy i zderzenia mikroskopijnie małych cząstek pyłków kwiatowych ,zawieszonych” w gazach i cieczach. Próby opisu tego zjawiska w języku prędkości zawiodły. Wszystko natomiast w sposób matematyczny wyjaśniły dwie prace: A. Einsteina Über die von der molekularkinetischen Theorie der Wärme geforderte Bewegung von in ruhenden Flüssigkeiten suspendierten Teilchen z $1905 \mathrm{r}^{41}$ oraz M. Smoluchowskiego Zur kinetischen Theorie der Brownschen Molekularbewegung und der Suspensionen z roku $1906^{42}$. Dość ciekawą cechą ruchów Browna jest to, że dokąd pójdziemy w następnym kroku zależy tylko od tego, gdzie się znajdujemy teraz. Tu można już mówić o tzw. łańcuchach Markowa. Proces Markowa to ciąg zdarzeń, w którym prawdopodobieństwo każdego zdarzenia zależy jedynie od wyniku poprzedniego. W ujęciu matematycznym procesy Markowa to takie procesy stochastyczne, które spełniają własność Markowa. Łańcuchy Markowa to procesy Markowa $\mathrm{z}$ czasem dyskretnym. Łańcuch Markowa jest

\footnotetext{
${ }^{40}$ DELIo, „Iannis Xenakis, Nomos Alpha”, 83.

${ }^{41}$ Albert EINSTEIN, „Über die von der molekularkinetischen Theorie der Wärme geforderte Bewegung von in ruhenden Flüssigkeiten suspendierten Teilchen”, Annalen der Physik nr 17 (1905): 549-560.

${ }^{42}$ Marian SMOLuchowsKi, „Zur kinetischen Theorie der Brownschen Molekularbewegung und der Suspensionen”, Annalen der Physik 21 (1906): 756-780.
} 
ciągiem $X_{1}, X_{2}, X_{3}, \ldots, X_{n}$ zmiennych losowych. Dziedzinę tych zmiennych nazywamy przestrzenią stanów, a realizacje $X_{n}$ to stany w czasie $n$. Jeśli rozkład warunkowy $X_{n+1}$ jest funkcją wyłącznie zmiennej $X_{n}$ :

$$
P\left(X_{\mathrm{n}+1} \leq y \mid X_{0}, X_{1}, X_{2}, \ldots, X_{\mathrm{n}}\right)=P\left(X_{\mathrm{n}+1} \leq y \mid X_{\mathrm{n}}\right),
$$

to mówimy, że proces stochastyczny posiada własność Markowa. Przedstawiona definicja zakłada czas dyskretny. Jak teraz Xenakis wykorzystywał ruchy Browna i łańcuchy Markowa? Jaki to miało wpływ na kompozycję? Tradycyjne utwory muzyczne są w większości przewidywalne, tzn. po usłyszeniu nawet niewielkiego fragmentu utworu wiemy, co będzie dalej. Dzięki użyciu ruchów Browna i łańcuchów Markowa przy komponowaniu, np. utwory z serii ST, utwory Xenakisa są nieprzewidywalne i niepowtarzalne.

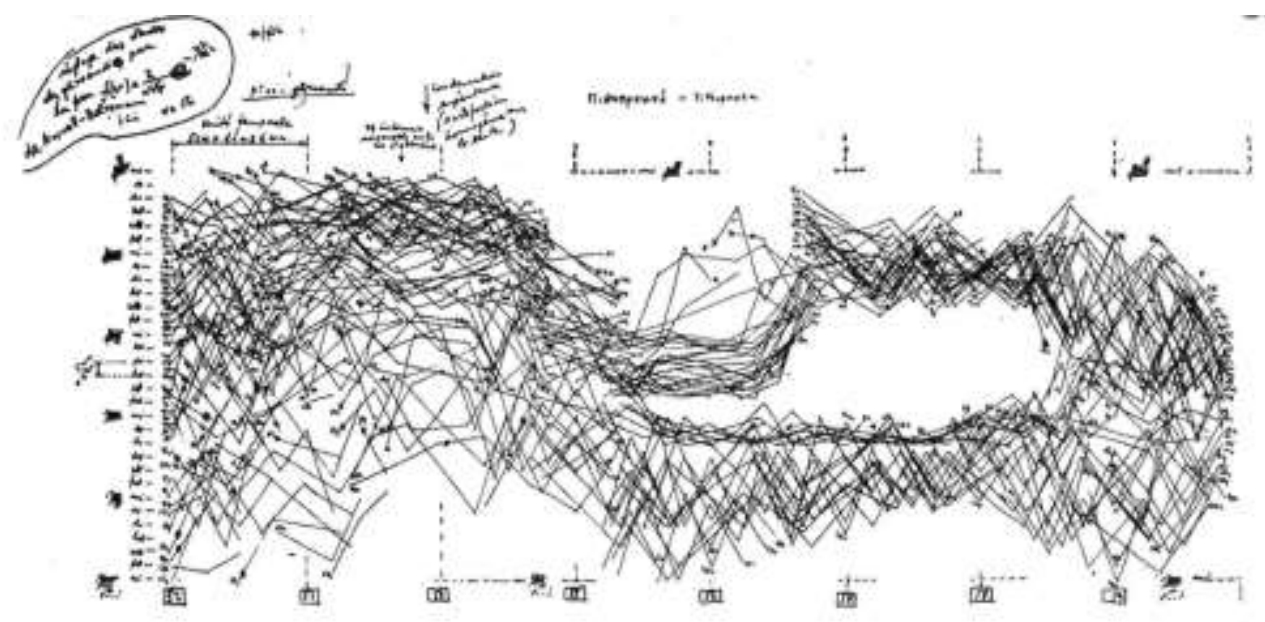

Rysunek 8. Glissanda w Pithoprakta ${ }^{43}$

Zastosowanie praw kinetyki można zauważyć w utworze Diamorphoses. To pierwsza kompozycja elektroakustyczna Xenakisa. Powstała między 1957 i 1958 r. i jest uważana za arcydzieło, o czym pisano w kilku książkach naukowych $\mathrm{z}$ zakresu historii muzyki elektroakustycznej ${ }^{44}$. W utworze tym

\footnotetext{
${ }^{43}$ Iannis XENAKIS, „Metamuzyka Xenakisa”, przeł. Wojciech Jachimiak, Glissando nr 4 (2005): 76-89. Pierwotnie publikowane jako „Appendix I” w: Iannis XenAKIS, Musique, Architecture (Tournai: Casterman, 1976).

${ }^{44}$ Makis Solomos, Xenakis pierwsza kompozycja w musique beton Diamorphoses (Université de Paris, 2014).
} 
Xenakis tak rozpisał głosy dla każdego instrumentu, że nie da się rozpoznać melodii każdego z nich, natomiast kształt całej masy dźwiękowej jest wyraźny.

\section{TEORIA GIER}

Kolejnym modelem matematycznym wykorzystanym w muzyce przez kompozytora jest teoria gier, którą zastosował w utworze Duel (1959 r.) i Strategie (1962 r.).

Aby lepiej je zrozumieć, należy zapoznać się z podstawowymi wiadomościami z zakresu teorii gier. Teoria gier to dział matematyki zajmujący się badaniem optymalnego zachowania w przypadku konfliktu interesów. Można ją określić jako teorię podejmowania decyzji w szczególnych warunkach. Gra to dowolna sytuacja konfliktowa, gracz natomiast to dowolny jej uczestnik. Każda strona wybiera pewną strategię postępowania, po czym zależnie od strategii własnej oraz innych uczestników każdy gracz otrzymuje wypłatę w jednostkach użyteczności. Zależnie od gry jednostki te mogą reprezentować pieniądze, wzrost szansy na przekazanie własnych genów czy też cokolwiek innego, z czystą satysfakcją włącznie. Wynikowi gry zwykle przyporządkowuje się pewną wartość liczbową. Teoria gier bada, jakie strategie powinni wybrać gracze, żeby osiągnąc najlepsze wyniki. Z sytuacjami gier spotykamy się $\mathrm{w}$ wielu sytuacjach społecznych, a teoria racjonalnego rozwiązywania gier ma bardzo szerokie zastosowanie i pozwala na lepsze znajdowanie właściwego rozwiązania.

Do ważniejszych rodzajów gier należą:

- gra o sumie zerowej - gra, w której interesy obu graczy są dokładnie przeciwstawne; osoba pierwsza wygrywa dokładnie tyle, ile przegrywa druga,

- gra o sumie niezerowej - gra, w której wypłaty obu graczy nie sumują się do zera,

- gra macierzowa - gra dwuosobowa o sumie zerowej, która jest macierzą $m \times n$, gdzie $m$ to liczba strategii jednej osoby, a $n$ to liczba strategii drugiej. Celem osoby pierwszej jest taki wybór wiersza, by uzyskać wynik reprezentowany przez największą wartość, drugiej - wybór kolumny, w której wynik gry jest liczbą najmniejszą.

Dodatkowo należy jeszcze zdefiniować kilka pojęć z teorii gier potrzebnych do analizy muzyki Xenakisa: 
1. Strategia $S$ dominuje strategię $\boldsymbol{T}$, jeżeli każdy wynik dawany przez $S$ jest co najmniej równie korzystny co odpowiedni wynik dawany przez $T$, a przynajmniej jeden wynik dawany przez $S$ jest bardziej korzystny niż odpowiedni wynik dawany przez $T$.

2. Kryterium dominacji - racjonalny gracz nigdy nie wybiera strategii zdominowanej.

3. Punkt równowagi - taki wynik gry macierzowej, dla którego strategie graczy są wzajemnie najlepszymi odpowiedziami na siebie. W takim przypadku wypłata dla tej pary strategii jest jednocześnie największa w swoim wierszu i najmniejsza w swojej kolumnie.

4. Punkt siodłowy - wynik gry macierzowej (dla macierzy zawierającej wypłaty gracza wybierającego wiersze), jeżeli jego wartość jest mniejsza lub równa każdej wartości w jego wierszu, a większa lub równa każdej wartości w jego kolumnie.

5. Kryterium punktu siodłowego - jeżeli gra macierzowa ma punkt siodłowy, obaj gracze powinni wybrać zawierające go strategie.

6. Wartość gry - dla każdej gry macierzowej, dla której istnieje taka liczba $v$, że osoba I ma strategię gwarantującą jej wygranie co najmniej $v$, a osoba II ma strategię gwarantującą, że osoba I nie wygra więcej, $v$ jest wartością gry.

Jeżeli gra ma punkt siodłowy, to jego wartość jest wartością gry. Niektóre gry nie mają żadnego punktu siodłowego, inne mają ich kilka. Gdy gra ma wiele punktów siodłowych, wszystkie one są ze sobą powiązane - mają tę samą wartość i leżą na wierzchołkach jednego prostokąta.

7. Twierdzenie. Każde dwa punkt siodłowe tej samej gry mają taką samą wartość. Jeżeli zarówno osoba I, jak i osoba II zagrają strategie zawierające punkty siodłowe, to wynik gry zawsze będzie punktem siodłowym.

Jak znaleźć punkt siodłowy?

- wypisujemy najmniejsze wartości z każdego wiersza i wybieramy największą spośród nich, zwaną maksyminem,

- wypisujemy największe wartości z każdej kolumny i wybieramy najmniejszą z nich, zwaną minimaksem.

Strategie te nazywamy maksyminową i minimaksową. Jeśli maksimin wierszy i minimaks kolumn jest taki sam, to leży on w punkcie siodłowym. Jeżeli maksimin i minimaks mają różne wartości, gra nie posiada punktu siodłowego.

Po tym wprowadzeniu poddajmy analizie utwór Xenakisa Duel. Podczas wykonywania tego utworu orkiestra podzielona jest na dwie grupy. Każda grupa ma swojego dyrygenta i każdy z nich wybiera spośród z góry określonych możliwości najlepszą odpowiedź na wybór dokonany przed chwilą przez 
poprzednika - oczywiście wg pewnych zasad. Zatem ostateczny kształt utworu zależy od interakcji: przypadek - decyzja. Kompozytor zaplanował w nim sześć zdarzeń (możliwości), które są wybierane przez dyrygenta:

Zdarzenie I. Grupa dźwięków, takich jak pizzicato uderzane drewnianą częścią smyczka rozchodzące się stochastycznie.

Zdarzenie II. Równoległe struny przytrzymywane z wahaniami.

Zdarzenie III. Splecione sieci glissando.

Zdarzenie IV. Stochastyczne dźwięki perkusyjne.

Zdarzenie V. Dźwięki instrumentów dętych grane z rozkładem stochastycznym (Stochastic wind instrument sounds).

Zdarzenie VI. Cisza.

Każde z tych zdarzeń jest bardzo precyzyjnie opisane w partyturze, co pozwala dyrygentowi $\mathrm{w}$ każdym momencie bezproblemowe rozpoczęcie i wykonywanie danego zdarzenia. Xenakis sporządził listę par wydarzeń wraz z subiektywną oceną tych połączeń, co przedstawia tabela 4.

\begin{tabular}{|c|c|}
\hline $\begin{array}{l}\text { Para } \\
(\mathrm{x}, \mathrm{y})=(\mathrm{y}, \mathrm{x})\end{array}$ & Ocena \\
\hline$(\mathrm{I}, \mathrm{I})$ & passable $(p)$ \\
\hline$(\mathrm{I}, \mathrm{II})=(\mathrm{II}, \mathrm{I})$ & $\operatorname{good}(g)$ \\
\hline$(\mathrm{I}, \mathrm{III})=(\mathrm{III}, \mathrm{I})$ & good $+(g+)$ \\
\hline$(\mathrm{I}, \mathrm{IV})=(\mathrm{IV}, \mathrm{I})$ & passable $+(p+)$ \\
\hline$(\mathrm{I}, \mathrm{V})=(\mathrm{V}, \mathrm{I})$ & very good $(g++)$ \\
\hline (II, II) & passable $(p)$ \\
\hline$(\mathrm{II}, \mathrm{III})=(\mathrm{III}, \mathrm{II})$ & passable $(p)$ \\
\hline$(\mathrm{II}, \mathrm{IV})=(\mathrm{IV}, \mathrm{II})$ & $\operatorname{good}(g)$ \\
\hline$(\mathrm{III}, \mathrm{V})=(\mathrm{V}, \mathrm{III})$ & passable $+(p+)$ \\
\hline (III, III) & passable $(p)$ \\
\hline$(\mathrm{III}, \mathrm{IV})=(\mathrm{IV}, \mathrm{III})$ & good $+(g+)$ \\
\hline$(\mathrm{III}, \mathrm{V})=(\mathrm{V}, \mathrm{III})$ & $\operatorname{good}(g)$ \\
\hline$(\mathrm{IV}, \mathrm{IV})$ & passable $(p)$ \\
\hline$(\mathrm{IV}, \mathrm{V})=(\mathrm{V}, \mathrm{IV})$ & $\operatorname{good}(g)$ \\
\hline$(\mathrm{V}, \mathrm{V})$ & passable $(p)$ \\
\hline
\end{tabular}

Tabela 4. Tabela ocen ${ }^{45}$

\footnotetext{
${ }^{45}$ Xenakis, Formalized Music (1992),114.
} 
Można te połączenia przedstawić również za pomocą tabeli 5 (w wersji bez zdarzenia Cisza) oraz ze zdarzeniem Cisza, co pokazuje tabela 6.

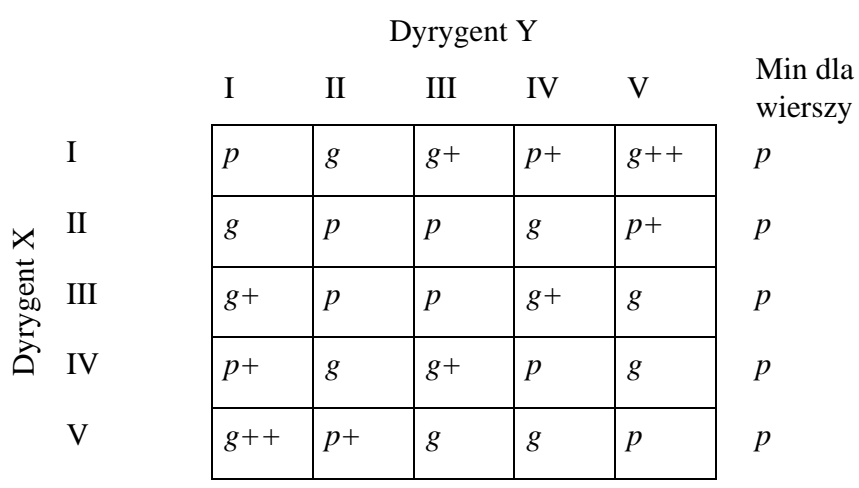

$\begin{array}{llllll}\text { Max dla } & g++ & g & g+ & g+ & g++\end{array}$

Tabela 5. Tabela zdarzen ${ }^{46}$

Zauważamy, że punkty siodłowe w tym przypadku nie istnieją (największe minimum $\mathrm{w}$ wierszach nie jest równe najmniejszemu maksimum w kolumnach). Zatem nie ma jasnych strategii. Systuacja się zmienia, gdy dodamy do macierzy zdarzenie VI - Cisza.

Dyrygent $\mathrm{Y}$

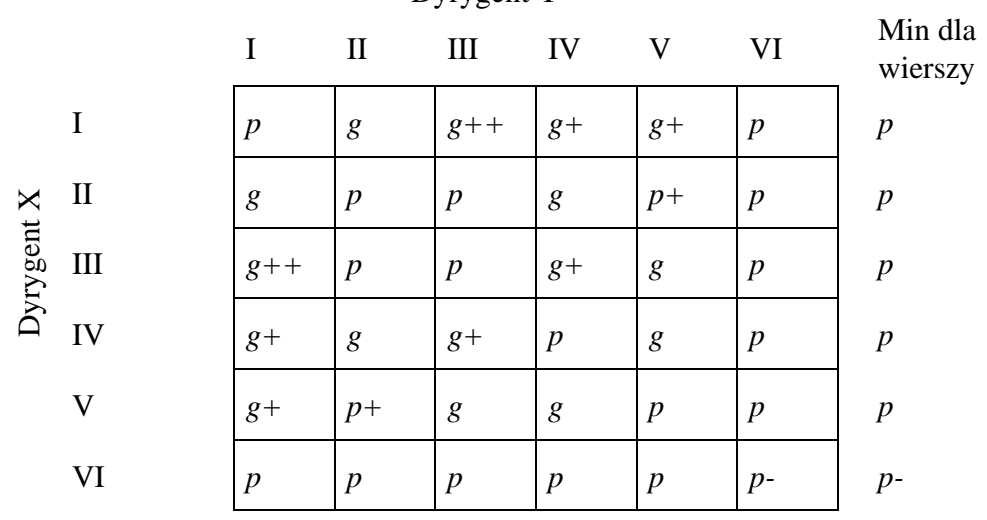

Max dla kolumn

$$
g++\quad g \quad g++\quad g+\quad g+\quad p
$$

Tabela 6. Tabela zdarzeńn ${ }^{47}$

\footnotetext{
${ }^{46}$ Ibidem, 115.

${ }^{47}$ Ibidem, 115.
} 
Tym razem mamy kilka punktów siodłowych. Wszystkie strategie są możliwe, jednak bliższa analiza pokazuje, że konflikt jest nadal. Dyrygent Y może zagrać zdarzenie VI tylko wtedy, gdy dyrygent $\mathrm{X}$ zagra zdarzenie I, II, III, IV lub V. Grę rozpoczyna dyrygent $X$, zatem gra zależy od niego. Ponadto zasady są zbyt ogólnikowe. Xenakis nadał tym połączeniom kolejne wartości - tym razem wagi, co pokazuje tabela 7 .

\begin{tabular}{|l|l|l|l|l|l|}
\hline$p-$ & $p$ & $p+$ & $g$ & $g+$ & $g++$ \\
\hline 0 & 1 & 2 & 3 & 4 & 5 \\
\hline
\end{tabular}

Tabela 7. Tabela wag $^{48}$

Dodatkowo połączenie (VI, VI) ma wagę 3. Tabela 8 przedstawia kolejną wersję par zdarzeń.

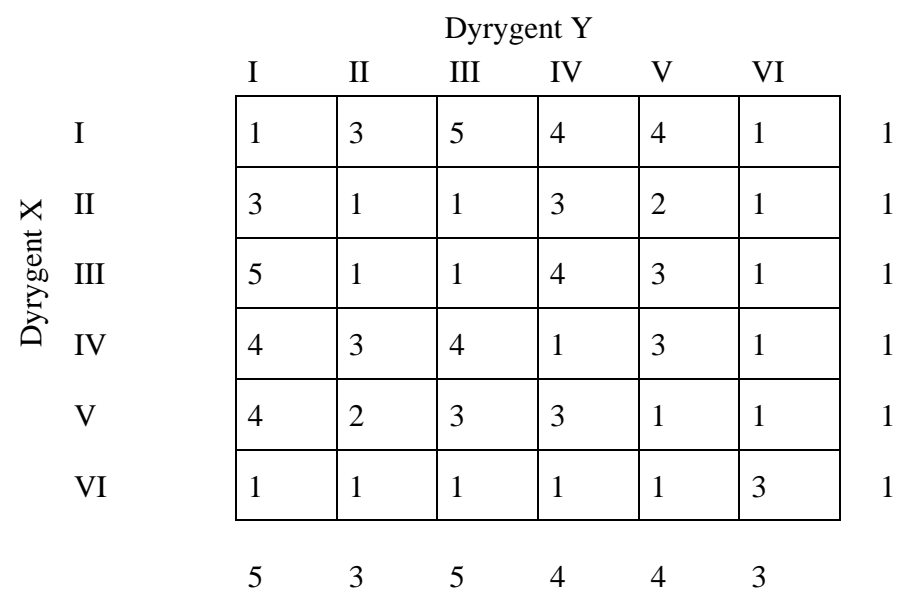

Tabela 8. Tabela zdarzeniowo-wagowa ${ }^{49}$

Nie istnieją jednak teraz punkty siodłowe i żadne wiersze czy kolumny recesywne. Aby znaleźć strategię, można posłużyć się metodą aproksymacji. Celem jest znalezienie strategii, w której żadna waga nie jest zerowa. Niemożliwe jest podanie wszystkich kalkulacji. Macierz ta może wyglądać jak w tabeli 9, gdzie widzimy dwie unikatowe strategie dla dyrygenta $\mathrm{X}$ oraz $\mathrm{Y}$.

\footnotetext{
${ }^{48}$ Ibidem, 116.

${ }^{49}$ Ibidem, 116.
} 


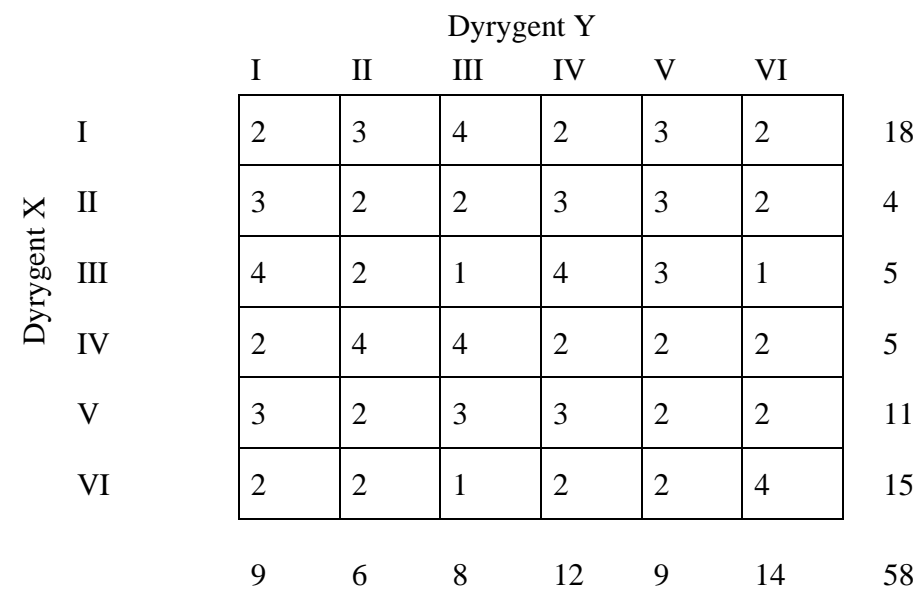

Tabela 9. Tabela zdarzeniowo-wagowa ${ }^{50}$

Dyrygent $\mathrm{X}$ musi zatem odgrywać zdarzenia I, II, III, IV, V, VI odpowiednio $w$ proporcjach: $18 / 58,4 / 58,5 / 58,5 / 58,11 / 58,15 / 58$ podczas gdy dyrygent $\mathrm{Y}$ odgrywa je odpowiednio w proporcjach $9 / 58,6 / 58,8 / 58,12 / 58$, $9 / 58,14 / 58$. Wartość gry w tym momencie wynosi około 2,5 na korzyść dyrygenta X. Kolejnym etapem jest eksperymentalna kontrola macierzy. Możliwe są dwa sposoby:

1. Symulować grę, zamieniając między sobą dyrygentów.

2. Wybierać zdarzenia zupełnie losowo, ale z częstotliwością (częstością) proporcjonalnie do wartości marginesowych (brzegowych).

Okazuje się, że eksperymentalne wartości gry są bardzo zbliżone do wartości aproksymacji (przybliżonych). Procesy dźwiękowe są również zadowalające. Można stosować teraz kolejne eksperymenty, m.in. można zastosować bardziej rygorystyczny sposób optymalizacji strategii dla X i Y, stosując algorytm sympleksowy ${ }^{51}$.

Ostateczny kształt utworu zależy zatem od interakcji: przypadek - decyzja. Każdy z dwóch dyrygentów wybiera sprośród z góry określonych możliwości najlepszą odpowiedź na wybór dokonany przez poprzednika ${ }^{52}$.

\footnotetext{
${ }^{50}$ Ibidem, 117.

51 „Algorytm sympleksowy - inaczej metoda sympleks(ów) - iteracyjna metoda rozwiązywania zadań programowania liniowego za pomocą kolejnego polepszania (optymalizacji) rozwiązania", https://pl.wikipedia.org/wiki/Algorytm_sympleksowy (dostęp: 4.03.2017).

${ }^{52}$ XeNAKIS, ,Metamuzyka”, 84.
} 


\section{ZAKOŃCZENIE}

Xenakis posiadał wiedzę $\mathrm{z}$ wielu dziedzin, co dawało mu przewagę nad innymi $\operatorname{artystami}^{53} \mathrm{~W}$ procesie „umuzyczniania matematyki”. Wykorzystanie na tak szeroką skalę modeli, struktur i obiektów matematycznych powoduje, że jego muzyka jest niezwykle wymagająca dla kompozytora i wykonującego ją muzyka, a także wymaga od słuchacza odpowiednich predyspozycji intelektualnych lub dużej wrażliwości emocjonalnej. Xenakis wspominał, że po wykonaniu jego utworu Anaktoria muzycy zespołu Octour de Paris potrzebowali przerwy, bo nie byli w stanie grać dalej, tak byli zmęczeni fizycznie. Nasuwa się zatem pytanie: jak wielu jest słuchaczy muzyki Xenakisa? Na podstawie przeprowadzonych ankiet stwierdzono, że wśród prawie dwóch tysięcy osób ani jedna nie zetknęła się z jego muzyką i praktycznie o nim nie słyszeli. Można zadać sobie też kolejne pytania: czy Xenakis dbał o słuchacza, czy dbał o popularność? Przecież jest wielu kompozytorów, którzy myślą tylko o tym, jak się przypodobać słuchaczowi i zdobyć w ten sposób popularność. Xenakis do tej grupy na pewno nie należy, co wpływa na brak popularności. Jego muzyka jest asemantyczna i abstrakcyjna, bo nie tworzy żadnego języka i użyte w niej wzory nie naśladują niczego. Odbiór muzyki jest złożonym procesem poznawczym, któremu może towarzyszyć m.in. analiza i synteza materiału muzycznego, skojarzenia i wyobrażenia, a także estetyczne i emocjonalne przeżycia. Problematyką percepcji muzyki interesowano się już w czasach starożytnych, a od końca XIX w. badania percepcji muzyki stanowią jedną z głównych gałęzi psychologii muzyki. W ich skład wchodzą m.in. psychoakustyczne badania percepcji dźwięku (wysokość, głośność, barwa), interwałów, elementów muzycznych (melodia, harmonia, agogika, rytm, forma, styl), a także badania psychoestetyczne. Percepcja muzyki jest uzależniona od wielu czynników, m.in. od rodzaju muzyki, jej wykonania, właściwości indywidualnych odbiorcy: słuch muzyczny, pamięć muzyczna, wyobraźnia muzyczna czy zdolność koncentracji uwagi. Również i uwarunkowania historyczne i kulturowe mają wpływ na percepcję. Muzykę odbieramy poprzez zmysł słuchu, który jest bardzo zróżnicowany u każdego człowieka. Najpowszechniej poprawnie człowiek odbiera rytm, potem wysokość dźwięku, harmonię, barwę, aż w końcu cały przebieg utworu, a więc jego formę. Każdy człowiek ma swój własny próg uznania tego, co jest przyjemną melodią czy formą w muzyce. Słuch cechuje się pewną akceptowalną niedokładnością. Szczególną jego własnością jest czułość na różnice

\footnotetext{
${ }^{53}$ Ibidem, 86.
} 
wysokości, co z kolei wiąże się z melodią. Przejawami słuchu muzycznego jest m.in. zapamiętywanie, rozpoznawanie i odtwarzanie dźwięków. Te cechy są niezbędnym warunkiem właściwej percepcji.

Muzyka Xenakisa przeciwstawiała się jakiejkolwiek tradycji w muzyce dzięki zastosowaniu w niej modelowania matematycznego. Wykonywał on miesiącami wiele obliczeń potrzebnych do skomponowania utworu wg zasad matematyki. Zadanie to ułatwił później komputer. Dzięki zastosowaniu matematyki Xenakis stał się architektem nowych brzmień. Jego muzyka była nieprzewidywalna, ale nie przypadkowa, ponieważ była całkowicie kontrolowana przez procesy matematyczne. Na pewno nie jest to aleatoryzm. Chaos, niepewność, nieuporządkowanie w jego muzyce to tylko pozory. To po prostu tak „surowe" i zaawansowane matematycznie przekształcenia, że wielu słuchaczy nie jest w stanie odbierać tej muzyki „na zasadzie relaksacyjnej”. Zauważmy jednak, że techniki imitacyjne (np. inwersja, rak, augmentacja tematów w fugach czy kanonach) opierają się na przekształceniach matematycznych, a jednak jesteśmy w stanie odbierać dużą część muzyki polifonicznej „na zasadzie relaksacyjnej”. Zatem przyjemność estetyczną, jaką możemy mieć ze słuchania jakiejś kompozycji muzycznej, nie wymaga wiedzy o strukturze formalnej tej kompozycji. W muzyce Xenakisa mamy do czynienia z o wiele bardziej złożonymi modelami matematycznymi. Gdy słuchacz wie, czym kierował się Xenakis przy komponowaniu, na pewno lepiej będzie mógł zrozumieć, dlaczego właśnie tak brzmi ta muzyka.

To, że kompozytor posłużył się w danym utworze metodą wyboru dźwięków wymodelowaną matematycznie, wiemy z reguły dzięki pozyskanym wcześniej informacjom. Od dawna wszak wiadomo - i wniosek ten potwierdzają również eksperymenty psychologiczne - że nawet stosunkowe proste struktury matematyczne nie są przez ludzki słuch należycie identyfikowane w bezpośredniej percepcji słuchowej oraz że uzmysławiamy je sobie, a i to $\mathrm{z}$ wielkim trudem, dopiero gdy zostaniemy o nich powiadomieni. Jest to być może główny powód, dla którego „muzyka matematyczna”, z którą eksperymentowano głównie latach pięćdziesiątych i sześćdziesiątych ubiegłego wieku, nie zdobyła nigdy u większości słuchaczy zrozumienia ani uznania.

Czy nasz artysta ma swoich następców? Czy jego muzyka inspirowała kolejnych kompozytorów?

Xenakis był artystycznym samotnikiem, ale krąg stylistyczny, który w latach pięćdziesiątych i sześćdziesiątych aprobował, nawiązując np. współpracę z kompozytorami działającymi w studio radiowym w Paryżu założonym i kierowanym przez Pierre'a Schaeffera, miał licznych i wpływowych przedstawicieli, którzy jego pomysły kompozytorskie rozszerzyli i ubogacili, 
głównie dzięki praktyce transformowania i zestawiania ze sobą elementów elektronicznych i konkretnych, co doprowadziło do wyzwolenia dźwięku ze skali temperowanej oraz uwolnienia go od źródeł mechanicznych (instrumentalnych); uczynił to np. Edgar Varèse. W ten sposób główna idea filozoficzna Xenakisa mówiąca, że błędne jest dopatrywanie się w muzyce języka, albowiem jest ona w swej istocie jedynie porządkiem czasoprzestrzennym, doczekała się u innych awangardowych kompozytorów tamtego okresu swoistego rozwinięcia i realizacji. Jednym z nich był również polski kompozytor Zbigniew Karkowski, którego James Harley - autor książki Xenakis: His Life in Music - nazywa spadkobiercą Xenakisa. Sam Karkowski był uczniem Xenakisa, Messiaena, Bouleza i Arperghisa. Ciekawym wy darzeniem muzycznym był projekt Karkowski/Xenakis project z 2015 r. polegający na połączeniu muzyki Xenakisa z muzyką Karkowskiego.

Nie można jednak zapominać, że w pod koniec XX stulecia większość europejskich i amerykańskich kompozytorów zrezygnowała z eksperymentowania dźwiękowego, a nadmierne formalizowanie procesu komponowania, do czego skłaniał się Xenakis, uznała za błąd.

$\mathrm{Na}$ zakończenie warto wspomnieć o sztucznej inteligencji i algorytmach, które potrafią wykorzystać modele matematyczne i stworzyć kompozycję muzyczną $\mathrm{w}$ dowolnym stylu. Wystarczy maszynie podać małą próbkę muzyki, np. Bacha czy Mozarta, dodać do tego odpowiedni algorytm i pojawi się kompozycja, którą zdecydowanie możemy odbierać „na zasadzie relaksacyjnej". Mamy wiele programów tego typu, np. Google Magenta czy IBM Watson Beats, które radzą sobie z tym doskonale. Również roboty wykonują muzykę rockową czy jazzową. Słynny robot Shimon jest wirtuozem gry na marimbie. Jego szkolenie odbywało się na podstawie ponad pięciu tysiący utworów jazzowych i klasycznych oraz na prawie dwóch milionach riffów i motywów muzycznych. Obecnie robot nie tylko koncertuje z żywymi muzykami, ale i komponuje. Jednym z najlepszych przykładów tego, że algorytmy sztucznej inteligencji świetnie sprawdzają się w roli kompozytorów muzycznych, jest projekt Aiva (Artificial Intelligence Virtual Artist). Algorytm ten został uznany za pełnoprawnego kompozytora przez francuski odpowiednik polskiego ZAIKS-u.

Zdefiniowane wcześniej pojęcie „umuzyczniania matematyki” czy modelowanie matematyczne w muzyce jest wciąż aktualne i ciągle się rozwija. Ponadto, przy wykorzystaniu algorytmów sztucznej inteligencji można wziąc pod uwagę wiele innych czynników (atrybutów kompozycji) sprawiających, że taka „matematyczna muzyka” może być odbierana „na zasadzie relaksacyjnej” czy jako „piękna” w klasycznym znaczeniu słowa „piękny”. 


\section{BIBLIOGRAFIA}

BARrow, John. Wszechświat a sztuka. Przeł. Janusz Skolimowski. Warszawa: Amber, 1998.

BAumgarten, Aleksander. Aesthetica. Frankfurt a. Oder: Traiecti as Viadrum Jo. Christ. Kleyb, 1750.

Bronsztejn, Igor, Konstantin SiemiendiAJEw. Matematyka - Poradnik encyklopedyczny. Warszawa: PWN, $1976^{6}$.

BrożeK, Anna. Symetria w muzyce. Tarnów: Biblos, 2004.

ChOMIŃski, Józef, Krystyna WilkowsKa-Chomińska. Teoria formy. Kraków: Polskie Wydawnictwo Muzyczne, 1983.

CyCERON. „De oratore III 50”. W Historia estetyki, t. I, przeł. Władysław Tatarkiewicz. Warszawa: Arkady, 1985.

DAHLhaus, Carl. Estetyka muzyki. Warszawa: Wydawnictwo UW, 2015.

DeLio, Thomas. „Iannis Xenakis' "Nomos Alpha”, The Dialectics of Structure and Materials”. Journal of Music Theory vol. 24, no. 1 (Spring, 1980): 63-95.

DiAz-JEREZ, Gustavo. Algorytmic music: using mathematical models in music composition, [maszynopis]. The Manhattan School: 2000.

DiTTRICH, Joanna. „Filozofia Muzyki Arystoksenosa”. Zeszyty Naukowe Towarzystwa Doktorantów UJ 2, nr specjalny 3 (2011): „Kierunki badawcze w filozofii II”: 153-162.

EINSTEIN, Albert. „Über die von der molekularkinetischen Theorie der Wärme geforderte Bewegung von in ruhenden Flüssigkeiten suspendierten Teilchen", Annalen der Physik vol. 322, z. 8 (1905): s. 549-560.

Fauvel, John, Raymond Flood, Robin Wilson, ed. Music and Mathematics. From Pythagoras to Fractals. Oxford: Oxford University Press, 2003.

GręBSKI, Tomasz. „Muzyka sfer”, Wiedza i Życie nr 9 (969) (2015): s. 54-59.

HANSLICK, Eduard. Von Musikalisch-Schönen. Leipzig: Breitkopf \& Härtel, 1854.

HARLEY, James. „Iannis Xenakis Diamorphoses, for 2-track tape \& at least 4 loudspeakers”, Allmusic.com, Rovi Corporation, 2014.

HARLeY, James. Xenakis: His Life in Music. New York and London: Routledge, 2004.

Hofstadter, Douglas Richard. Gödel, Escher, Bach: An Eternal Golden Braid. New York: Basic Books , 1979.

Matossian, Nouritza. Xenakis. London: Kahn \& Averill, 1986.

Montassier, Gérard. Le fait culturel. Paris: Editions Fayard, 1980.

OrMAN, Edyta. „Muzyka na tle innych sztuk w ujęciu Thrabsybulosa Georgiadesa”. W 10 Polski Zjazd Filozoficzny 15-19 września 2015 Poznań, red. Lidia Godek, Maciej Musiał, Marek Woszczek. Poznań: Wydawnictwo Naukowe Instytutu Filozofii UAM, 2015.

SCHOPEnhauer, Arthur. Świat jako wola i przedstawienie, t. I. Przeł. Jan Garewicz. Warszawa: PWN, 1994.

SchumanN, Robert. Schriften über Music und Musiker, t. 1. Leipzig: Georg Wigand's Verlag, 1888.

SMOLUCHOwSKI, Marian. „Zur kinetischen Theorie der Brownschen Molekularbewegung und der Suspensionen”, Annalen der Physik 326, z. 14 (2006): 756-780. 
Solomos, Makis. Xenakis pierwsza kompozycja w musique beton Diamorphoses. Université de Paris, 2014.

TAtarkiewicz, Władysław. Dzieje sześciu pojęć. Warszawa: PWN, 1988.

West, Martin. Muzyka starożytnej Grecji. Tłum. Anna Maciejewska, Maciej Kaziński. Kraków: Homini, 2003.

XENAKIS, Iannis. „Debussy a sformalizowanie muzyki”. Ruch muzyczny $\mathrm{nr} 16$ (1962).

XeNAKIS, Iannis. „Metamuzyka Xenakisa”. Tłum. Wojciech Jachimiak. Glissando nr 4 (2005): 76-89. Pierwotnie publikowane jako „Appendix I” w Musique, Architecture. Tournai: Casterman, 1976.

XeNAKIS, Iannis. „Stochastische Musik”. Gravesaner Blätter” 23/24 (1962): 156-168.

XenAKIS, Iannis. Art/Sciences: Alloys: the thesis defense of Iannis Xenakis before Olivier Messiaen, Michel Ragon, Olivier Revault dÁllonnes, Michel Serres and Bernard Tayssàdre. Styvesant, NY: Pendragon Press, 1985.

Xenakis, Iannis. Formalized Music. Hillsdale, N.Y.: Pendragon Press, 1992.

XENAKIS, Iannis. Formalized Music. Thought and Mathematics in Music. Stuyvesant, NY: Pendragon Press, 1962.

\section{NETOGRAFIA}

https://archirama.muratorplus.pl/architektura/modernizm-reaktywacja-odnowa-pawilonu-stacji-pkpochota, 67_19.html (dostęp: 4.03.2017).

https://commons.wikimedia.org/w/index.php?curid=47467617 (dostęp: 15.04.2017).

https://commons.wikimedia.org/w/index.php?curid=68272 (dostęp: 4.03.2017).

https://commons. wikimedia.org/w/index.php?curid=68272 (dostęp: 4.03.2017).

https://en.wikiarquitectura.com/index.php/File:Pabellon_philips_boceto_2.jpg (dostęp: 15.04.2017).

https://upload.wikimedia.org/wikipedia/commons/e/e7/Expo58_building_Philips.jpg (dostęp: 12.12.2016).

\section{MODELOWANIE MATEMATYCZNE W MUZYCE NA PODSTAWIE TWÓRCZOŚCI IANNISA XENAKISA}

\section{Streszczenie}

Poszukiwanie matematycznych zależności w dziełach muzycznych to bardzo częste zjawisko badawcze. Można napotkać wiele utworów, w których artysta świadomie wykorzystywał wiedzę matematyczną podczas ich komponowania. Poszukiwanie matematycznych zależności w muzyce można by nazwać „matematyzowaniem muzyki”. Ale czy można „umuzycznić matematykę”, a dokładniej - obiekty matematyczne? W artykule analizie poddany jest problem ,umuzyczniania matematyki”, zaś celem artykułu jest przedstawienie wybranych struktur matematycznych świadomie użytych przez Iannisa Xenakisa w kompozycjach. Jego twórczość jest doskonałym przykładem połączenia matematyki $\mathrm{z}$ muzyką. Mowa tu o procesach stochastycznych i rachunku prawdopodobieństwa, o teorii grup, o ruchach Browna i łańcuchach Markowa oraz o teorii gier. Muzyka Xenakisa przeciwstawiała się jakiejkolwiek tradycji w muzyce dzięki zastosowaniu w niej modelowania matematycznego. Była nieprzewidywalna, ale nie przypadkowa. W artykule mowa również o procesie twórczym przy komponowaniu muzyki oraz o matematycznym 
porządku w utworach muzycznych i walorach estetycznych i artystycznych. Artykuł ten dodatkowo ułatwi odbiór muzyki Xenakisa i pozwala lepiej zrozumieć jego twórczość.

Słowa kluczowe: matematyka; muzyka; procesy stochastyczne; teoria gier; Xenakis; estetyka; matematyczne modelowanie; percepcja.

\section{MATHEMATICAL MODELING IN MUSIC} BASED ON THE WORK OF IANNIS XENAKIS

\section{Summary}

The search for mathematical relationships in musical compositions are often studied. There are many musical compositions, in which the composer consciously used mathematical knowledge during their composing. The search for mathematical dependence in music could be called "mathematization of music". Can we use math to music illustration of mathematical objects? The problem of using music to math illustration is analyzed in this article and the aim of the article is to present some mathematical structures consciously used in the compositions by Iannis Xenakis. His work is an excellent example of the connection of mathematics with music. There are described stochastic processes and probability theory, group theory, game theory, and Brownian motion and Markov chains. Music of Xenakis opposed any tradition in music by using mathematical modeling in it. It was unpredictable, but not accidental. There is also about the creative process when composing music and about mathematical order in musical works, as well as aesthetic and artistic values. This article facilitates the perception of Xenakis music and enables to understand his work better.

Key words: maths; music; stochastic processes; game theory; Xenakis; aesthetics; mathematical modeling; perception. 